\title{
Structural Response of Phyllomanganates to Wet Aging and Aqueous Mn(II)
}

\author{
Margaret A. G. Hinkle*, Elaine D. Flynn, and Jeffrey G. Catalano \\ Department of Earth and Planetary Sciences, Washington University, 1 Brookings Drive, Saint \\ Louis, MO 63130 USA \\ *Corresponding author: Tel.: +1-202-633-1815; E-mail: mhinkle@eps.wustl.edu
}

†Present address: Department of Mineral Sciences, Smithsonian Institution, National Museum of Natural History, Washington, DC 20560

\author{
Submitted to Geochimica et Cosmochimica Acta \\ May 2016 \\ Revised July 2016
}




\section{ABSTRACT}

Naturally occurring Mn(IV/III) oxides are often formed through microbial Mn(II)

43 oxidation, resulting in reactive phyllomanganates with varying $\mathrm{Mn}(\mathrm{IV}), \mathrm{Mn}(\mathrm{III})$, and vacancy

44 contents. Residual aqueous Mn(II) may adsorb in the interlayer of phyllomanganates above

45 vacancies in their octahedral sheets. The potential for interlayer Mn(II)-layer Mn(IV)

46 comproportionation reactions and subsequent formation of structural $\mathrm{Mn}(\mathrm{III})$ suggests that

47 aqueous $\mathrm{Mn}(\mathrm{II})$ may cause phyllomanganate structural changes that alters mineral reactivity or

48 trace metal scavenging. Here we examine the effects of aging phyllomanganates with varying

49 initial vacancy and $\mathrm{Mn}(\mathrm{III})$ content in the presence and absence of dissolved $\mathrm{Mn}(\mathrm{II})$ at $\mathrm{pH} 4$ and

50 7. Three phyllomanganates were studied: two exhibiting turbostratic layer stacking $\left(\delta-\mathrm{MnO}_{2}\right.$ with

51 high vacancy content and hexagonal birnessite with both vacancies and Mn(III) substitutions)

52 and one with rotationally ordered layer stacking (triclinic birnessite containing predominantly

$53 \mathrm{Mn}(\mathrm{III})$ substitutions). Structural analyses suggest that during aging at $\mathrm{pH} 4, \mathrm{Mn}(\mathrm{II})$ adsorbs

54 above vacancies and promotes the formation of phyllomanganates with rotationally ordered

55 sheets and mixed symmetries arranged into supercells, while structural Mn(III) undergoes

56 disproportionation. These structural changes at $\mathrm{pH} 4$ correlate with reduced $\mathrm{Mn}(\mathrm{II})$ uptake onto

57 triclinic and hexagonal birnessite after 25 days relative to 48 hours of reaction, indicating that

58 phyllomanganate reactivity decreases upon aging with $\mathrm{Mn}(\mathrm{II})$, or that recrystallization processes

59 involving $\mathrm{Mn}(\mathrm{II})$ uptake occur over 25 days. At $\mathrm{pH}$ 7, Mn(II) adsorbs and causes limited

60 structural effects, primarily increasing sheet stacking in $\delta-\mathrm{MnO}_{2}$. These results show that

61 aging-induced structural changes in phyllomanganates are affected by aqueous $\mathrm{Mn}(\mathrm{II}), \mathrm{pH}$, and

62 initial solid-phase $\mathrm{Mn}(\mathrm{III})$ content. Such restructuring likely alters manganese oxide reactions

63 with other constituents in environmental and geologic systems, particularly trace metals and

64 redox-active compounds. 


\section{INTRODUCTION}

Many naturally-occurring manganese oxides are nanoparticulate, poorly crystalline, and

67 highly reactive minerals (Krumbein and Jens, 1981; Emerson et al., 1982; Villalobos et al., 2003;

68 Saratovsky et al., 2006; Bargar et al., 2009; Clement et al., 2009; Dick et al., 2009; Grangeon et

69 al., 2010; Tan et al., 2010). Manganese oxide formation in natural systems is often controlled by

70 microbial $\mathrm{Mn}(\mathrm{II})$ oxidation, as abiotic $\mathrm{Mn}(\mathrm{II})$ oxidation is kinetically slow (Morgan and Stumm,

71 1964; Nealson et al., 1988; Tebo, 1991; Wehrli et al., 1995; Tebo et al., 1997; Von Langen et al.,

72 1997; Bargar et al., 2000; Nelson and Lion, 2003; Morgan, 2005; Luther, 2010). Biogenic

73 manganese oxides are typically phyllomanganates with birnessite-type structures, consisting of

74 negatively charged octahedral sheets separated by hydrated interlayers (Krumbein and Jens,

75 1981; Emerson et al., 1982; Villalobos et al., 2003; Bargar et al., 2005; Webb et al., 2005a;

76 Saratovsky et al., 2006; Bargar et al., 2009; Clement et al., 2009; Dick et al., 2009; Grangeon et

77 al., 2010; Tan et al., 2010; Santelli et al., 2011). The negative layer charge develops as a result of

$78 \mathrm{Mn}(\mathrm{IV})$ vacancies, $\mathrm{Mn}(\mathrm{III})$ substitutions, or a combination thereof, with vacancy and $\mathrm{Mn}(\mathrm{III})$

79 content varying substantially among phyllomanganates. To compensate the negative charge,

80 exchangeable cations are adsorbed in the interlayer. These phyllomanganates exhibit high

81 adsorption capacities for many cations, including Mn(II) (Morgan and Stumm, 1964; McKenzie,

82 1980; Murray et al., 1984), which often bind above vacant sites in the octahedral sheets (Toner et

83 al., 2006; Peacock and Sherman, 2007; Manceau et al., 2007b; Peacock, 2009; Zhu et al., 2010b)

84 and can enter into the phyllomanganate structure over time (Peacock, 2009).

85 Phyllomanganates coexist with aqueous $\mathrm{Mn}(\mathrm{II})$ in regions with active manganese cycling;

86 for example, at hydrothermal vents, redox interfaces in soils or sediments, or in oxic regions of

87 stratified soils, sediments, and water columns as a result of upward diffusion of Mn(II) (Graybeal 
and Heath, 1984; Rajendran et al., 1992; Burdige, 1993; Van Cappellen et al., 1998; Tebo et al., 2004; Tebo et al., 2005). Abiotic reactions involving Mn(II) adsorption onto phyllomanganates are likely common in these environments (Shimmield and Price, 1986; Canfield et al., 1993), and could involve $\mathrm{Mn}(\mathrm{II})$ incorporation into vacant sites or electron transfer via $\mathrm{Mn}(\mathrm{II})-\mathrm{Mn}(\mathrm{IV})$ comproportionation reactions, resulting in increased structural Mn(III). Several studies have identified that aqueous $\mathrm{Mn}(\mathrm{II})$ induces phyllomanganate phase transformations to a wide range of $\mathrm{Mn}(\mathrm{III})$ or $\mathrm{Mn}(\mathrm{IV} / \mathrm{III})$ oxide minerals, including nsutite $\left[\mathrm{Mn}(\mathrm{O}, \mathrm{OH})_{2}\right]$, ramsdellite $\left[\mathrm{MnO}_{2}\right]$, cryptomelane $\left[\mathrm{K}_{\mathrm{x}}\left(\mathrm{Mn}^{\mathrm{IV}}, \mathrm{Mn}^{\mathrm{III}}\right)_{8} \mathrm{O}_{16}\right]$, groutite $[\alpha-\mathrm{MnOOH}]$ (Tu et al., 1994), hausmannite $\left[\mathrm{Mn}_{3} \mathrm{O}_{4}\right]$ (Lefkowitz et al., 2013), feitknechtite [ $\left.\beta-\mathrm{MnOOH}\right]$ (Bargar et al., 2005; Elzinga, 2011; Lefkowitz et al., 2013; Elzinga and Kustka, 2015), or manganite [ $\gamma-\mathrm{MnOOH}]$ (Tu et al., 1994; Elzinga, 2011; Lefkowitz et al., 2013; Elzinga and Kustka, 2015). A recent study has observed Mn isotope exchange between aqueous $\mathrm{Mn}(\mathrm{II})$ and a solid $\mathrm{Mn}$ (IV) oxide during conversion to $\mathrm{Mn}(\mathrm{III})$ oxyhydroxides, indicating that some $\mathrm{Mn}(\mathrm{III})$ formed during reaction undergoes disproportionation (Elzinga and Kustka, 2015).

Many natural systems with active manganese cycling are associated with Mn(IV/III) phyllomanganates, even in the presence of elevated dissolved Mn(II) (Wehrli et al., 1995; Friedl et al., 1997; Manceau et al., 2007a; Manceau et al., 2007b; Dick et al., 2009; Tan et al., 2010; Frierdich and Catalano, 2012), suggesting that Mn(II)-induced phase transformations of birnessite-type phyllomanganates are uncommon. Prior research on Mn(II)-phyllomanganate interactions with $\mathrm{Mn}$ (II) to $\mathrm{Mn}(\mathrm{IV})$ ratios that do not induce phase transformations is limited. Some studies do indicate that Mn(II) alters sheet stacking behaviors (Lefkowitz et al., 2013) and symmetries (Bargar et al., 2005; Zhu et al., 2010a; Zhao et al., 2016). This indicates that structural $\mathrm{Mn}(\mathrm{III})$ was produced during reaction, as its larger size and Jahn-Teller distortion are 
111 expected to alter the mineral structure. However, the systematic relationship between $\mathrm{Mn}$ (II)

112 concentrations and phyllomanganate structural changes at low to circumneutral $\mathrm{pH}$ (conditions

113 relevant to soils and many natural waters) is unclear.

114 Identifying the structural response of phyllomanganates to dissolved $\mathrm{Mn}$ (II) is needed

115 because the reactivity and trace metal scavenging behavior of manganese oxides is largely

116 controlled by their structure (Post, 1999). In this paper, changes to phyllomanganate structures

117 are examined following aging for 25 days in the presence and absence of $\mathrm{Mn}$ (II) at acidic and

118 neutral $\mathrm{pH}$, with $\mathrm{Na}^{+}$as the dominant cation. Because $\mathrm{Mn}$ (II) likely adsorbs above vacancies,

119 three birnessite-type phyllomanganates with varying vacancy content and layer stacking are

120 investigated. $\delta$ - $\mathrm{MnO}_{2}$, the synthetic analogue of vernadite $\left[(\mathrm{Ca}, \mathrm{Na}, \mathrm{K})\left(\mathrm{Mn}^{4+}, \square\right) \mathrm{O}_{2} \bullet \mathrm{nH}_{2} \mathrm{O}\right]$

121 (Villalobos et al., 2006), has high vacancy content and turbostratic stacking; c-disordered $\mathrm{H}^{+}$

122 birnessite (a hexagonal-type birnessite) ('HexB') $\left[(\mathrm{Ca}, \mathrm{Na}, \mathrm{K})\left(\mathrm{Mn}^{4+}, \mathrm{Mn}^{3+}, \square\right) \mathrm{O}_{2} \bullet \mathrm{nH}_{2} \mathrm{O}\right]$ has

123 vacancies (Silvester et al., 1997; Lanson et al., 2000), Mn(III) substitutions, and turbostratic

124 stacking; triclinic birnessite ('TriB') $\left[(\mathrm{Ca}, \mathrm{Na}, \mathrm{K})\left(\mathrm{Mn}^{4+}{ }_{\mathrm{x}} \mathrm{Mn}^{3+}{ }_{1-\mathrm{x}}\right) \mathrm{O}_{2} \cdot \mathrm{nH}_{2} \mathrm{O}\right]$ has primarily $\mathrm{Mn}(\mathrm{III})$

125 substitutions, few vacancies, and ordered layer stacking (Post and Veblen, 1990; Drits et al.,

126 1997; Post et al., 2002; Lopano et al., 2007). The role of $\mathrm{pH}$ is also examined because

$127 \mathrm{Mn}(\mathrm{II})-\mathrm{Mn}(\mathrm{IV})$ comproportionation reactions exhibit a $\mathrm{pH}$ dependence, with comproportionation

128 promoted with increasing $\mathrm{pH}$ (Mandernack et al., 1995). The effects of aging and Mn(II) on

129 phyllomanganate sheet structures were explored using X-ray absorption fine structure (XAFS)

130 spectroscopy and powder X-ray diffraction (XRD). To assess differences in Mn(II) uptake upon

131 aging versus adsorption over short time scales, macroscopic $\mathrm{Mn}(\mathrm{II})$ adsorption isotherms onto

132 the solids at differing $\mathrm{pH}$ values were also obtained. 


\section{METHODS AND MATERIALS}

\subsection{Mn Oxide Syntheses}

Manganese oxide minerals were synthesized using modified, previously published procedures, as described in detail below. $\delta-\mathrm{MnO}_{2}$ was synthesized using a redox method, which involves the reduction of $\mathrm{KMnO}_{4}$ and the oxidation of $\mathrm{MnCl}_{2}$ under alkaline conditions, outlined by Villalobos et al. (2003). Briefly, a solution of $2.50 \mathrm{~g} \mathrm{KMnO}_{4}$ in $80 \mathrm{~mL}$ deionized water $(>18.2$ $\mathrm{M} \Omega \cdot \mathrm{cm}$ ) was added to a solution of $1.75 \mathrm{~g} \mathrm{NaOH}$ in $90 \mathrm{~mL}$ deionized water over approximately five minutes. While stirring this mixture vigorously, a solution of $4.70 \mathrm{~g} \mathrm{MnCl}_{2} \bullet 4 \mathrm{H}_{2} \mathrm{O}$ in $80 \mathrm{~mL}$ deionized water was added slowly, over approximately 35 minutes. The mixture was allowed to settle for four hours, after which point the $\mathrm{pH}$ of the suspension was checked to ensure it was around a $\mathrm{pH}$ of 7, and the suspension was centrifuged, discarding the supernatant. The suspension was subjected to at least four $1 \mathrm{M} \mathrm{NaCl}$ washes, as described in Villalobos et al. (2003), followed by at least six deionized water washes.

A poorly crystalline hexagonal birnessite was synthesized following the c-disordered $\mathrm{H}^{+}$-birnessite synthesis procedure described in Villalobos et al. (2003). This synthesis is similar to the $\delta-\mathrm{MnO}_{2}$ synthesis described above (including the $\mathrm{NaCl}$ and deionized water washes), except the $\mathrm{NaOH}$ solution consisted of $1.83 \mathrm{~g} \mathrm{NaOH}$ in $90 \mathrm{~mL}$ deionized water, the $\mathrm{Mn}$ (II) solution consisted of $5.82 \mathrm{~g} \mathrm{MnCl}_{2} \bullet 4 \mathrm{H}_{2} \mathrm{O}$ in $80 \mathrm{~mL}$ deionized water, and the $\mathrm{pH}$ of the suspension prior to centrifugation was near 3.1. Triclinic birnessite was prepared following the synthesis for Na-birnessite outlined in Lopano et al. (2007), based on the synthesis procedures described by Post and Veblen (Post and Veblen, 1990) and Golden et al. (1986; 1987). In this synthesis, a $5.5 \mathrm{M} \mathrm{NaOH}$ solution and a $0.5 \mathrm{M} \mathrm{MnCl}_{2} \bullet 4 \mathrm{H}_{2} \mathrm{O}$ solution were chilled in an ice bath while air was vigorously bubbled through the $\mathrm{Mn}$ (II) solution. Once the solutions were chilled to 
$1575^{\circ} \mathrm{C}$, the $\mathrm{NaOH}$ solution was added to the $\mathrm{Mn}(\mathrm{II})$ solution over approximately 3 minutes under a

158 fume hood. The resulting suspension was bubbled with air overnight in the fume hood. The

159 suspension was washed by an initial centrifugation to remove the basic supernatant, followed by

160 filtration $\left(0.45 \mu \mathrm{m}\right.$ nylon membrane, Whatman $\left.{ }^{\circledR}\right)$ and washing with deionized water until the $\mathrm{pH}$

161 of the filtrate was below 10.

162 After synthesis, the minerals were resuspended in DI water, transferred to an anaerobic

163 chamber (Coy Laboratory Products, Inc., $3 \% \mathrm{H}_{2} / 97 \% \mathrm{~N}_{2}$ atmosphere with Pd catalysts) and

164 sparged for at least 24 hours with a gas filtration system (Hinkle et al., 2015) to remove

165 dissolved $\mathrm{O}_{2}$ from the suspensions. The minerals were stored within the anaerobic chamber as

166 suspensions in deionized water in aluminum foil-wrapped polypropylene bottles and were used

167 for experiments within the month. Aliquots of the mineral suspensions were dried at $70{ }^{\circ} \mathrm{C}$ for

168 surface area analysis by BET $\mathrm{N}_{2}$ gas adsorption (Quantachrome Instruments Autosorb-1).

\subsection{Reagent preparation}

All stock solutions for experiments conducted in this study were prepared in the

172 anaerobic chamber using deoxygenated deionized water. The Mn(II) stock solution was prepared

173 from $\mathrm{MnCl}_{2} \bullet 4 \mathrm{H}_{2} \mathrm{O}$ and stored in an amber polypropylene bottle to prevent photo-oxidation. $\mathrm{NaCl}$

174 and 2-(4-morpholino)ethanesulfonic acid (MES) stock solutions were also prepared. For

175 experiments conducted at $\mathrm{pH} 7$, a stock solution comprised of both $\mathrm{NaCl}$ and $\mathrm{MES}$ was prepared

176 and adjusted to $\mathrm{pH} 7$ using $\mathrm{HCl}$ or $\mathrm{NaOH}$ solutions, which were sparged using the gas filtration

177 systems more than six months prior to use. The $\mathrm{HCl}$ and $\mathrm{NaOH}$ solutions were also used to 178 adjust experiment sample $\mathrm{pH}$. 


\subsection{Solid Mn(IV/III) Oxide Aging Experiments}

The effect of $\mathrm{Mn}(\mathrm{II})$ on phyllomanganate sheet structures was explored by collecting

182 XAFS spectra and XRD patterns on phyllomanganates reacted with varying concentrations of

$183 \mathrm{Mn}(\mathrm{II})$. In these experiments, $10 \mathrm{mM} \mathrm{NaCl}$ (required to buffer ionic strength) and 0, 0.75, or 7.5

$184 \mathrm{mM} \mathrm{Mn}(\mathrm{II})$ were reacted with $2.5 \mathrm{~g} \mathrm{~L}^{-1} \delta-\mathrm{MnO}_{2}, \mathrm{HexB}$, or TriB at $\mathrm{pH} 4$ or 7 for 25 days in an

185 anaerobic chamber (Coy Laboratory Products, Inc., 3\% $\mathrm{H}_{2} / 97 \% \mathrm{~N}_{2}$ atmosphere with $\mathrm{Pd}$

186 catalysts). $1 \mathrm{mM}$ MES pH buffer was used for TriB $\mathrm{pH} 7$ experiments as well as preliminary $\mathrm{pH}$

$1877 \delta-\mathrm{MnO}_{2}$ and $\mathrm{HexB}$ experiments.

188 For samples reacted with $\mathrm{Mn}(\mathrm{II})$, the ratio of initial aqueous $\mathrm{Mn}$ (II) to solid $\mathrm{Mn}(\mathrm{IV})$

189 (mol:mol) in these experiments range from 0.042-0.543 (Table 1). Samples were prepared in 15

$190 \mathrm{~mL}$ or $50 \mathrm{~mL}$ conical centrifuge tubes for the XAFS and XRD analyses, respectively. The $\mathrm{pH}$ of

191 the samples were monitored throughout the experiments. At the end of 25 days, the final $\mathrm{pH}$ of

192 each sample was recorded and the samples were filtered (reusable syringe filter; $0.22 \mu \mathrm{m} \mathrm{MCE}$

193 membrane; Fisher Scientific) to collecting the solids and supernatant fluid for analyses; the first

$1941 \mathrm{~mL}$ of supernatant was discarded. The fluid was acidified to $2 \% \mathrm{HNO}_{3}$ (trace metal grade;

195 Fisher Scientific) immediately after removal from the anaerobic chamber. Aliquots of the

196 acidified fluid were diluted using $2 \% \mathrm{HNO}_{3}$ and analyzed for total Mn concentration by

197 inductively-coupled plasma optical emission spectroscopy (ICP-OES) using a Perkin Elmer

198 Optima 7300 DV instrument. Sample uncertainty (95\% confidence level) was calculated for

199 these samples by the triplicate instrument analyses.

\section{$201 \quad 2.4$ XRD Analyses}

202 For XRD analyses, the samples were dried at ambient temperature $\left(22 \pm 1^{\circ} \mathrm{C}\right)$ in a vacuum 
203 desiccator, then ground with an agate mortar and pestle and stored within glass vials, all within

204 the anaerobic chamber. XRD slides were prepared in the anaerobic chamber and sealed with an

205 airtight dome to maintain anoxic conditions. However, use of the dome substantially attenuated

206 the X-ray beam intensity, decreasing the signal to noise ratio, and produced large background

207 scattering features at 9 to $18^{\circ}$ and above $65^{\circ} 2 \theta$. XRD patterns were collected for all samples

208 reacted with $7.5 \mathrm{mM} \mathrm{Mn}$ (II) with and without the dome to test the stability of these materials in

209 air during analysis (approximately 40 minutes). No changes were observed between patterns

210 collected with and without the dome for these high Mn(II) experiments, consistent with the

211 known slow kinetics of $\mathrm{Mn}(\mathrm{II})$ oxidation by $\mathrm{O}_{2}$ (Morgan, 2005; Luther, 2010). All other samples

212 were thus assumed to be air-stable for the duration of the XRD analyses and were measured only

213 in air; all XRD presented here were collected without the dome. To minimize air exposure, these

214 were transferred to the XRD instrument within the airtight dome, which was removed

215 immediately prior to data collection. Unreacted phyllomanganates were dried immediately after

216 synthesis and were prepared and analyzed following the same methods for the aged samples, but

217 in air rather than under anaerobic conditions. XRD patterns were collected from $5-80^{\circ} 2 \theta$ with

$2180.04^{\circ} 2 \theta$ steps at 3 seconds step ${ }^{-1}$ with $\mathrm{Cu}_{a}$ radiation, a LynxEyeXE Si strip detector, a $0.6 \mathrm{~mm}$

219 anti-scatter slit, and a $2.5^{\circ}$ incident soller slit, with the X-ray tube voltage and current set to 40

$220 \mathrm{kV}$ and $40 \mathrm{~mA}$, respectively.

221

\section{$222 \quad 2.5$ XAFS Spectroscopy}

\section{2.5.1 XAFS Data Collection}

224 Samples prepared for XAFS spectroscopic analyses were packed as wet pastes on a 225 syringe filter membrane enclosed in Kapton film and sealed with $25 \mu \mathrm{m}$ Kapton tape within the 
226 anaerobic chamber. Each XAFS sample was heat sealed in a polyethylene bag with a damp

227 KimWipe to maintain anoxic and hydrated conditions during transport to the Advanced Photon

228 Source (APS) at Argonne National Laboratory. Hydrated conditions were further ensured by

229 filtering and preparing the solids within 48 hours of transport to the APS. Wet pastes of

230 synthesized, unreacted $\delta-\mathrm{MnO}_{2}, \mathrm{HexB}$, and TriB were also filtered and prepared for XAFS

231 spectroscopic measurements as described above. XANES spectra of synthetic bixbytite

$232\left[\mathrm{Mn}_{2} \mathrm{O}_{3}\right]$, rhodochrosite $\left[\mathrm{MnCO}_{3}\right]$, and $1 \mathrm{M} \mathrm{MnSO}_{4(\mathrm{aq})}$ were also collected. The minerals were

233 prepared for XAFS spectroscopy by grinding with an agate mortar and pestle for approximately

23415 minutes and spreading the resulting fine powder on Scotch tape. The $1 \mathrm{M} \mathrm{MnSO}_{4}$ solution

235 was prepared for XAFS measurements by sealing the solution in a polycarbonate sample holder

236 with Kapton tape.

237 XAFS spectra were collected in transmission at beamlines 5-BM-D and 12-BM-B at the

238 Advanced Photon Source (APS) at Argonne National Laboratory. 5-BM-D uses a Si (111)

239 fixed-offset double-crystal monochromator, which was detuned by $40 \%$ to decrease harmonics in

240 the incident X-ray beam. Rh-coated Si mirrors optimize the beam height and further reduce the

241 harmonic content. 12-BM-B also uses a Si (111) fixed-offset double-crystal monochromator,

242 which was detuned by $20 \%$, and has toroidal focusing and flat harmonic rejection mirrors. XAFS

243 spectra of a Mn metal foil, collected simultaneously with each sample scan, was used to calibrate

244 the monochromators to the Mn K-edge $(6539 \mathrm{eV})$.

$246 \quad$ 2.5.2 XAFS Spectral Fitting

247 The XAFS spectra were averaged, processed, and normalized using the Athena (Ravel

248 and Newville, 2005) interface to IFEFFIT (Newville, 2001). The average manganese oxidation 
state (AMOS) for each sample was calculated using linear combination fitting (LCF) of the

250 normalized XANES spectra in Athena with the following manganese oxidation state standards:

$251 \mathrm{MnCO}_{3}, 1 \mathrm{M} \mathrm{MnSO}_{4(\mathrm{aq})}$, bixbyite, feitknechtite, and three $\mathrm{Mn}(\mathrm{IV})$ standards in the database

252 provided in Manceau et al. (2012): KBi (a $\mathrm{K}^{+}$-birnessite), ramsdellite, and pyrolusite (Figure

253 EA1). These fits followed a modified approach described Manceau et al. (2012), in which six or

254 fewer reference oxidation state standards with non-negative loadings are fit to a sample using

255 LCF. The accuracy of these manganese oxidation valence state fits are difficult to calculate

256 through traditional methods, but are estimated to be \pm 0.04 v.u., with decreasing accuracy with

257 increasing $\mathrm{Mn}^{3+/ 2+}$ content (Manceau et al., 2012).

258 Fitting of the $\mathrm{k}^{3}$-weighted EXAFS spectra was conducted in SixPack (Webb, 2005) using

259 a structural model similar to that described in detail by Webb et al. (2005a). A Na-birnessite

260 (phyllomanganate) structure (Post and Veblen, 1990) was used to calculate backscattering phase

261 and amplitude functions using FEFF 7 (Ankoudinov, 1996). The EXAFS spectra were fit over a

$262 \mathrm{k}$ range of $3-15.3 \AA^{-1}$ and an $\mathrm{R}$ range of $1-6 \AA$. The amplitude reduction factor $\left(\mathrm{S}_{0}{ }^{2}\right)$ was fixed

263 to 0.835 following Webb et al. (2005a). The model employed three Mn-O shells and three

264 Mn-Mn shells, with each shell including two paths to account for potential Jahn-Teller distorted

$265 \mathrm{Mn}(\mathrm{III})$-induced warping of the phyllomanganate sheet. Corner-sharing Mn-Mn (likely Mn

266 bound above sheet vacancies) and interlayer Mn-Na were also included in the model. All five

267 possible Mn-Mn multiple scattering (MS) paths for the third Mn-Mn shell were included in the

268 model, but only contributed 1 additional fitting variable $\left(\sigma^{2}\right)$ to the fit as their coordination

269 numbers and distances could be constrained fully using the constituent single scattering (SS)

270 paths. The $\sigma^{2}$ values between linked paths were fixed, and second and third shell Mn-Mn

271 distances were fixed based on the geometrical constrains defined by the first Mn-Mn shell. Every 
272 Mn-Mn scattering path included a parameter to account for vacancy effects on the amplitude,

$273 f_{o c c}$ : the fraction of Mn sites occupied in the phyllomanganate sheet. It should be noted that this

$274 f_{\text {occ }}$ parameter correlates strongly with particle size (Webb et al., 2005a). Attempts to include the

$275 \beta$ parameter from the Webb et al. (2005a) model to improve fitting a weak feature in the Fourier

276 transform spectra at $\sim 5.2 \AA(\mathrm{R}+\Delta \mathrm{R})$ generally yielded no effect on other structural parameters

277 (e.g., $f_{o c c}$ or Mn path splitting). $\beta$ did not vary systematically among the samples and often had

278 large uncertainties, with values within error of zero. As the feature at $\sim 5.2 \AA$ was adequately fit

279 (Figure EA2) by allowing a Mn-Mn MS $\sigma^{2}$ parameter to vary, the $\beta$ parameter was not included 280 in the final model.

\section{$282 \quad 2.6$ Macroscopic Mn(II) Adsorption Experiments}

$283 \mathrm{Mn}(\mathrm{II})$ adsorption isotherms were measured after 2 days of reaction for each

284 phyllomanganate mineral to assess $\mathrm{Mn}$ (II) uptake on short time scales compared to results 285 observed in the aging studies described above. All experiments were conducted within the 286 anaerobic chamber with $10 \mathrm{mM} \mathrm{NaCl}$ (to buffer ionic strength), $2.5 \mathrm{~g} \mathrm{~L}^{-1}$ phyllomanganate, and $2870.02-12 \mathrm{mM}$ aqueous $\mathrm{Mn}(\mathrm{II})$ at $\mathrm{pH}$ 4, wrapped in aluminum foil and rotated on end-over-end 288 rotators for two days. pH 7 studies were not conducted because no dissolved $\mathrm{Mn}$ (II) was detected 289 at the end of the aging studies, preventing comparison to short time scale adsorption isotherms.

290 Samples at $0.10 \mathrm{mM} \mathrm{Mn}$ (II) were prepared in triplicate and as mineral-free blanks to assess

291 systematic experimental errors. Samples were allowed to equilibrate for approximately an hour, 292 at which point the $\mathrm{pH}$ of each sample was adjusted using $\mathrm{HCl}$ or $\mathrm{NaOH}$. The sample $\mathrm{pH}$ was 293 checked and adjusted if necessary throughout the reaction period.

294 At the end of the experiments, the $\mathrm{pH}$ of the samples was recorded and the samples were 
295 filtered ( $0.22 \mu \mathrm{m}$ MCE filters; Fisher Scientific). The $\mathrm{pH}$ of all samples drifted by less than 0.1

$296 \mathrm{pH}$ units, except under high $\mathrm{Mn}(\mathrm{II})$ conditions [i.e., > $9 \mathrm{mM}$ initial $\mathrm{Mn}(\mathrm{II})$ ] with the TriB system,

297 which all had final $\mathrm{pH}$ drifts greater than $0.5 \mathrm{pH}$ units from the target $\mathrm{pH}$. Due to the large $\mathrm{pH}$

298 drifts in the TriB samples with $>9 \mathrm{mM}$ initial Mn(II), these samples were discarded from the

299 final reported isotherm. The filtrate was collected after discarding the first $1 \mathrm{~mL}$ of filtrate and

300 prepared for ICP-OES measurements as described above. Both the triplicate instrument analyses

301 and the standard deviations from the triplicate experiment samples (propagated to the entire

302 sample set) were used to calculate experimental uncertainty at $95 \%$ confidence level. The

303 adsorption data was fitted to Langmuir isotherms (Table EA1) to facilitate quantitative

304 comparison to $\mathrm{Mn}$ (II) uptake after aging.

\section{RESULTS}

\section{3.1 Synthesized Materials}

The three phyllomanganates used in this work, $\delta-\mathrm{MnO}_{2}, \mathrm{HexB}$, and TriB, exhibit

309 properties consistent with past studies (Villalobos et al., 2003; Webb et al., 2005a). HexB (167.8

$\left.310 \mathrm{~m}^{2} \mathrm{~g}^{-1}\right)$ and $\delta-\mathrm{MnO}_{2}\left(116.4 \mathrm{~m}^{2} \mathrm{~g}^{-1}\right)$ have much larger BET-derived surface areas than TriB $(24.8$

$311 \mathrm{~m}^{2} \mathrm{~g}^{-1}$ ), and the $\mathrm{Mn}(\mathrm{III})$ content decreases from TriB to $\mathrm{HexB}$ to $\delta-\mathrm{MnO}_{2}$ (Table EA2). The XRD

312 patterns of $\delta-\mathrm{MnO}_{2}$ and $\mathrm{HexB}$ (Figure 1A) exhibit broad, low-intensity (001) and (002) peaks

313 near 12.3 and $24.8^{\circ} 2 \theta$, respectively, indicating that few sheets are stacked along the $c$-axis [i.e.,

$314 \sim 1-4$ sheets (Lanson et al., 2008; Grangeon et al., 2010; Grangeon et al., 2012)]. The $\delta-\mathrm{MnO}_{2}$

315 and HexB XRD patterns also contain asymmetric $(20,11)$ and $(02,31)$ bands near 37 and $65^{\circ} 2 \theta$,

316 respectively, characteristic of turbostratic phyllomanganates (Villalobos et al., 2003; Webb et al.,

317 2005a; Webb et al., 2005b), with d-spacing ratios consistent with hexagonal sheet symmetry 
318 (i.e., d-spacing ratio of $(20,11) /(02,31) \sim \sqrt{ } 3)$ (Villalobos et al., 2003; Villalobos et al., 2006;

319 Grangeon et al., 2010). The HexB XRD pattern also exhibits a decrease in intensity near $46^{\circ} 2 \theta$

320 relative to the $(20,11)$ band maxima at $38^{\circ}$, indicating vacancies in the sheet are capped by $\mathrm{Mn}$ or

321 other cations (Villalobos et al., 2006; Grangeon et al., 2010; Grangeon et al., 2012). In contrast,

322 the TriB XRD pattern (Figure 1A) is consistent with rotationally ordered sheets with

323 pseudo-orthogonal symmetry and a large coherent scattering domain along the $c$-axis (Brindley

324 and Brown, 1980).

325 The EXAFS spectra (Figure 2) also indicate that $\delta-\mathrm{MnO}_{2}$ and $\mathrm{HexB}$ have hexagonal sheet

326 symmetry while TriB is pseudo-orthogonal. Prior work has shown that the positive antinodes at

$327 \sim 6.8, \sim 8.1$, and $9.2 \AA^{-1}$ shift to lower $\mathrm{k}$ values, with the latter two splitting, when

328 phyllomanganate sheets transition from hexagonal to pseudo-orthogonal symmetry (Marcus et

329 al., 2004; Manceau et al., 2005; Webb et al., 2005a; Zhu et al., 2010a; Yu et al., 2012). The

330 positive antinode at $\sim 6.8 \AA^{-1}$ is considered characteristic of layered manganese oxides

331 (McKeown and Post, 2001). These differences in sheet symmetry are manifested in the Fourier

332 transform spectra, with the Mn MS peak at $5.2 \AA(\mathrm{R}+\Delta \mathrm{R})$ becoming attenuated from sheet

333 bending arising from Jahn-Teller distorted Mn(III) substitution (Webb et al., 2005a; Bargar et al., 334 2009).

335 The EXAFS spectra are also sensitive to the presence of Mn atoms capping vacancy sites, 336 although quantification of the abundance of such species by this method is poor (Webb et al., 337 2005a). The dominant oxidation state of capping Mn atoms can be estimated by combining the 338 distance between these atoms and $\mathrm{Mn}$ atoms in the phyllomanganate sheet (the $\mathrm{Mn}-\mathrm{Mn}_{\mathrm{crnr}}$ path in 339 the structural fitting model; Table EA3), the AMOS (Table 2), and fine-structure features in the 340 XANES spectrum, specifically a shoulder at $\sim 6553 \mathrm{eV}$ that indicates the presence of sorbed 
341 Mn(II) (Bargar et al., 2000; Villalobos et al., 2003; Webb et al., 2005a). The Mn-Mn crnr $_{\text {distance }}$

342 (Table EA3) is shorter in TriB (3.36 $)$ ) than in HexB (3.45 $\AA$ ). The distance in TriB is consistent

343 with Mn(III), as Jahn-Teller distortion yields shorter corner-sharing Mn-Mn distances for this

344 oxidation state than for a $\mathrm{Mn}(\mathrm{II})$ neighbor (Post et al., 1982). For $\delta-\mathrm{MnO}_{2}$ the $\mathrm{AMOS}$ of 3.99

345 (Table 2), lack of a shoulder at $6553 \mathrm{eV}$, no distinct feature at $3.0 \AA \mathrm{(R}+\Delta \mathrm{R})$ in the Fourier

346 transform (corresponding to the $\mathrm{Mn}-\mathrm{Mn}_{\mathrm{crnr}}$ shell), and better EXAFS spectral fit when excluding

$347 \mathrm{Mn}-\mathrm{Mn}_{\mathrm{crnr}}$ from the model (Figure EA2) all indicate that few vacancy-capping Mn atoms are

348 present in unreacted $\delta-\mathrm{MnO}_{2}$. The $\mathrm{Mn}(\mathrm{II})$ content of the HexB material (Table EA2) and the

349 longer $\mathrm{Mn}-\mathrm{Mn}_{\mathrm{crnr}}$ distance suggest that interlayer Mn over vacancies is predominately $\mathrm{Mn}(\mathrm{II})$.

$351 \quad 3.2$ Effect of Aging and Mn(II) on Turbostratic Phyllomanganates

$352 \quad p H 4$

$353 \delta-\mathrm{MnO}_{2}$ and $\mathrm{HexB}$ sheet structures change substantially after 25 days of aging at $\mathrm{pH} 4$ in

354 both the absence and presence of aqueous Mn(II). XANES spectra (Figure 2) indicate that

355 AMOS decreases with increasing initial aqueous Mn(II) (Table 2), and the Fourier transforms of

356 the EXAFS spectra (Figure 2) suggest increased $\mathrm{Mn}-\mathrm{Mn}_{\mathrm{crnr}}$ contributions, both consistent with

$357 \mathrm{Mn}(\mathrm{II})$ sorption onto the phyllomanganates during the 25 day reaction. While Mn(II) uptake onto

$358 \delta-\mathrm{MnO}_{2}$ after aging closely matched uptake behavior observed on short time scales, adsorption

359 by HexB decreased upon aging (Figure 3). This suggests that structural properties of the

360 phyllomanganates change during aging.

361 The XRD patterns of $\delta-\mathrm{MnO}_{2}$ reacted with 0 and $0.75 \mathrm{mM} \mathrm{Mn}(\mathrm{II})$ at $\mathrm{pH} 4$ (Figure 1)

362 exhibit a minimum near $46^{\circ} 2 \theta$ compared to the unaged sample, consistent with Mn adsorption

363 over vacancies (Villalobos et al., 2006; Grangeon et al., 2010; Grangeon et al., 2012). The 
364 decrease in $f_{\text {occ }}$ (Table EA4) and AMOS of 3.99 (Table 2) for the $0 \mathrm{mM} \mathrm{Mn(II)} \mathrm{sample} \mathrm{suggests}$

365 that either Mn migrates out of the phyllomanganate sheet and into vacancy-capping sites or that

366 the phyllomanganate crystallite size simply decreases during aging, although the latter scenario

367 should be accompanied by an increase in the width of the $h k 0$ bands in XRD, which is not

368 observed (Figure 1). The small $\mathrm{Mn}-\mathrm{Mn}_{\mathrm{crnr}}$ contribution in the EXAFS model fit and its distance

369 of $3.28 \AA$ further indicate that some layer Mn(III/IV) is redistributed to the interlayer to adsorb

370 over vacancies upon $\delta-\mathrm{MnO}_{2}$ aging at $\mathrm{pH} 4$. For the $0.75 \mathrm{mM} \mathrm{Mn}$ (II) sample, however, the

371 AMOS and presence of a shoulder at $6553 \mathrm{eV}$ in the XANES spectrum indicate the addition of

372 sorbed $\mathrm{Mn}(\mathrm{II})$.

373 The XRD patterns of the $7.5 \mathrm{mM} \mathrm{Mn}(\mathrm{II}) \delta-\mathrm{MnO}_{2}$ sample and all aged HexB samples

374 exhibit substantial changes compared to the unreacted sample, with the $(11,20)$ and $(31,02)$

375 bands splitting and the appearance of additional peaks in the $20-70^{\circ} 2 \theta$ region (Figure $1 \mathrm{~B}, \mathrm{C}$ ).

376 These additional peaks do not correspond with the diffraction lines of known manganese oxides,

377 including tectomanganates like todorokite or cryptomelane (Table EA5). The additional XRD

378 peaks are thus not from the formation of a secondary manganese mineral. Similar peaks between

$379 \sim 35-70^{\circ} 2 \theta$ have been previously observed for an $\mathrm{H}$-exchanged hexagonal birnessite (' $\mathrm{HBi}$ ')

380 formed by equilibration of triclinic Na-buserite at pH 5 (Lanson et al., 2000) and for HBi with

381 Zn adsorbed over vacancies (Lanson et al., 2002; Drits et al., 2007). These were interpreted as

382 containing an interstratified defective layer structure (Lanson et al., 2000; Lanson et al., 2002;

383 Drits et al., 2007), as the $h k l$ peak positions in such cases lie between the $h k l$ positions of each of

384 the layer-types present in the material (Drits and McCarty, 1996). These materials were best

385 described by models consisting of interspersed hexagonal and orthogonal sheets with rotated

386 stacking behaviors and each sheet displaced along the a axis by $+\mathrm{a} / 3$ (Lanson et al., 2000; 
387 Lanson et al., 2002), analogous to the chalcophanite structure (Post and Appleman, 1988). This

388 structure minimizes electrostatic repulsion, maximizing the distance between $\mathrm{Mn}$ atoms in 389 adjacent sheets and the distance between sheet Mn sites and Mn atoms capping vacancies

390 (Lanson et al., 2000; Lanson et al., 2002). Analogous XRD patterns have been reported for 391 rotationally ordered Ca-montmorillonite, with $(11,20)$ and $(31,02)$ band splitting and relative 392 intensities similar to those observed in this paper (Viani et al., 2002).

393 This structural arrangement was further shown to produce supercell ordering in

394 phyllomanganates (Drits et al., 2002). XRD features in the $20-26^{\circ} 2 \theta$ region not associated with 395 the (002) reflection in the present study are consistent with supercell peaks previously observed 396 for this class of minerals (Drits et al., 1998). All of the samples with these XRD features have 397 weak layer stacking so the long range ordering responsible for the supercell must be located in 398 the $a-b$ plane. These results thus indicate that the phyllomanganate sheet structure formed after $399 \delta-\mathrm{MnO}_{2}$ reacts with $7.5 \mathrm{mM} \mathrm{Mn(II)}$ or when $\mathrm{HexB}$ is aged with or without added dissolved $400 \mathrm{Mn}(\mathrm{II})$ is likely a mixture of hexagonal and pseudo-orthogonal phyllomanganate sheets that are 401 rotationally ordered in their stacking and contain long-range sheet-parallel periodicity. These 402 aging-induced HexB structural changes may explain the observed reduction in $\mathrm{Mn}$ (II) uptake by $403 \mathrm{HexB}$ but not $\delta-\mathrm{MnO}_{2}$ upon aging relative to uptake over short time scales (Figure 3). The 404 initiation of this ordering transition in HexB under all aging conditions yet only at the highest $405 \mathrm{Mn}(\mathrm{II})$ loading for $\delta-\mathrm{MnO}_{2}$ suggests that a threshold $\mathrm{Mn}(\mathrm{III})$ content may exist, below which 406 rotational ordering and supercell formation do not occur upon aging. Valence state 407 measurements (Table 2) suggest that an AMOS less than $\sim 3.8$ is required to induce this 408 restructuring; in the samples studied, this corresponds to $10-15 \mathrm{~mol} \% \mathrm{Mn}(\mathrm{III})$.

409 The EXAFS spectra of $\delta-\mathrm{MnO}_{2}$ and $\mathrm{HexB}$ further confirm that the XRD features do not 
410 arise from a phase transformation but instead from changes in sheet symmetry and ordering, as

411 the primary phyllomanganate structure (i.e., $\mathrm{MnO}_{6}$ octahedra arranged in negatively charged

412 sheets) is preserved during aging and reaction with $\mathrm{Mn}(\mathrm{II})$ (Figure 2). Both $\mathrm{HexB}$ and $\delta-\mathrm{MnO}_{2}$

413 reacted with $0.75 \mathrm{mM} \mathrm{Mn}$ (II) exhibit minimal changes relative to the samples aged without

414 added $\mathrm{Mn}(\mathrm{II}) . \delta$ - $\mathrm{MnO}_{2}$ reacted with $7.5 \mathrm{mM} \mathrm{Mn}(\mathrm{II})$, however, shows dampening and slight

415 broadening of the 6.8 and $9.2 \AA^{-1}$ features in the EXAFS spectrum, which could be attributed to

416 the formation of a phyllomanganate with mixed sheet symmetries. All $\delta-\mathrm{MnO}_{2}$ and $\mathrm{HexB}$

417 samples that show evidence of mixed sheet symmetries and supercell ordering display either an

418 increase in splitting of the $\mathrm{Mn}-\mathrm{O}_{1}$ interatomic distances in the structural fitting model or a

419 reduction in splitting in this shell coupled with a large $\sigma^{2}$ value for the more distant $\mathrm{Mn}-\mathrm{O}_{1 \mathrm{~b}}$ shell

420 (Table EA4). We attribute these effects to the formation of a mixture of sheets with slightly

421 different structures that corresponds to the larger-scale structural changes identified by XRD. No

422 other systematic changes were apparent, indicating preservation of the overall phyllomanganate

423 sheet during aging and reaction with $\mathrm{Mn}(\mathrm{II})$ at $\mathrm{pH} 4$.

424

$425 \quad p H 7$

$426 \delta-\mathrm{MnO}_{2}$ and $\mathrm{HexB}$ aged at $\mathrm{pH} 7$ exhibit behavior considerably different than when

427 reacted at $\mathrm{pH} 4$. No substantial restructuring or formation of supercell ordering is observed at

428 higher $\mathrm{pH}$, with or without $\mathrm{Mn}(\mathrm{II})$ addition (Figure $1 \mathrm{~B}, \mathrm{C}) . \delta-\mathrm{MnO}_{2}$ shows sharper (001) and

429 (002) peaks after aging with $0.75 \mathrm{mM} \mathrm{Mn(II)} \mathrm{present} \mathrm{(Figure} \mathrm{1B),} \mathrm{indicating} \mathrm{that} \mathrm{more} \mathrm{sheets} \mathrm{are}$

430 stacked along the $c$-axis. For HexB aged with and without $0.75 \mathrm{mM} \mathrm{Mn}(\mathrm{II})$, the XRD patterns

431 (Figure 1C), EXAFS spectra (Figure 2) and structural fitting parameters (Table EA4) at pH 7 are

432 largely unchanged during aging and reaction with $\mathrm{Mn}(\mathrm{II})$, indicating little alteration of the 
433 phyllomanganate sheet structure occurs. Reduction of the AMOS (Table 2) and a decrease near

$43446^{\circ} 2 \theta$ in the XRD pattern (Figure 1) (Villalobos et al., 2006; Grangeon et al., 2010; Grangeon et

435 al., 2012) indicate that $\mathrm{Mn}(\mathrm{II})-\mathrm{HexB}$ interactions are primarily limited to $\mathrm{Mn}(\mathrm{II})$ adsorption

436 reactions at $\mathrm{pH} 7$. However, for both $\delta-\mathrm{MnO}_{2}$ and $\mathrm{HexB}$, structural changes and a decrease in

437 AMOS were observed at this $\mathrm{pH}$ in the presence of MES buffer (see Electronic Annex). All

438 samples reacted with higher $\mathrm{Mn}(\mathrm{II})$ concentrations, $7.5 \mathrm{mM}$, at $\mathrm{pH} 7$ exhibit substantial

439 feitknechtite precipitation as demonstrated by the corresponding XRD patterns (Figure 4A),

440 resulting in substantial changes in the XANES spectra (Figure 4B) and making it impossible to

441 assess how the structure of the residual phyllomanganate responds.

$443 \quad 3.3$ Effect of Aging and Mn(II) on TriB

$444 \quad p H 4$

445 Like $\delta-\mathrm{MnO}_{2}$ and $\mathrm{HexB}$, TriB also undergoes structural changes when aged at $\mathrm{pH} 4$ in the 446 absence and presence of aqueous $\mathrm{Mn}(\mathrm{II})$, although the changes to the TriB structure are distinct

447 from those displayed by the turbostratic phyllomanganates. The XRD patterns show that aging 448 TriB at this $\mathrm{pH}$ with or without added $\mathrm{Mn}(\mathrm{II})$ results in a hexagonally symmetric material with 449 weaker rotational ordering of layers than the unreacted sample (Figure 1D). The d-spacing ratio 450 between reflections in all TriB samples are $\sim 1.73$, in agreement with a hexagonal unit cell 451 (Villalobos et al., 2003; Villalobos et al., 2006; Grangeon et al., 2010). The EXAFS spectra 452 clearly show that TriB reacted at $\mathrm{pH} 4$ no longer possesses pseudo-orthogonal sheet symmetry, 453 as the maxima centered at $6.8,8.1$, and $9.2 \AA^{-1}$ in hexagonally symmetric phyllomanganates are 454 no longer shifted to lower $\mathrm{k}$ values as in unreacted TriB, and each is a single positive antinode. 455 Structural fitting of the spectra (Figure EA2) reveal that $\mathrm{Mn}-\mathrm{Mn}_{\mathrm{crnr}}$ distances increased 
456 from $3.36 \AA$ in unreacted TriB to $3.49 \AA$ in TriB aged in the absence and presence of Mn(II).

457 This change in $\mathrm{Mn}-\mathrm{Mn}_{\mathrm{crnr}}$ distances, in conjunction with the appearance of a shoulder at $\sim 6553$

$458 \mathrm{eV}$ and the white line shift toward higher energy in the XANES spectra (Figure 2G) (Bargar et

459 al., 2000; Villalobos et al., 2003; Webb et al., 2005a), indicate that Mn atoms capping vacancies

460 shift from predominately $\mathrm{Mn}(\mathrm{III})$ to $\mathrm{Mn}(\mathrm{II})$, and that this is coupled with an increase in structural

$461 \mathrm{Mn}(\mathrm{IV})$ content. Fitting of the XANES spectra reveal a decreasing Mn(III) content coupled with

462 increasing $\mathrm{Mn}(\mathrm{II})$ and $\mathrm{Mn}(\mathrm{IV})$ contents upon aging TriB at $\mathrm{pH} 4$ (Table EA2). Furthermore, the

463 amount of $\mathrm{Mn}(\mathrm{II})$ remaining in solution at the end of the $0 \mathrm{mM}$ and $0.75 \mathrm{mM} \mathrm{Mn}$ (II) 25 day

464 experiments is greater than the initial amount of $\mathrm{Mn}(\mathrm{II})$ added to the systems (Table 2),

465 indicating that $\mathrm{Mn}(\mathrm{II})$ is released to solution via disproportionation of structural Mn(III). In

466 contrast, $\mathrm{Mn}(\mathrm{II})$ uptake by TriB after 48 hours follows typical Langmuir isotherm adsorption

467 behavior (Figure 3), with no net Mn(II) release observed, demonstrating the role of aging in

468 altering the structure and reactivity of TriB. These observations are consistent with TriB

469 transitioning to a phyllomanganate with hexagonal symmetry as a result of aging for 25 days

470 under low $\mathrm{pH}$ conditions that favor $\mathrm{Mn}(\mathrm{III})$ disproportionation.

$471 \quad$ TriB samples reacted with differing amounts of aqueous $\mathrm{Mn}(\mathrm{II})$ show minor systematic

472 changes in the XRD patterns and EXAFS spectra. The Fourier transforms of the EXAFS spectra

473 (Figure 2I) show a slight shift in the first Mn-Mn shell position in the presence of $7.5 \mathrm{mM}$

$474 \mathrm{Mn}(\mathrm{II})$, as well as an increased intensity of the $\sim 3.0 \AA$ feature corresponding to the $\mathrm{Mn}-\mathrm{Mn}_{\mathrm{crnr}}$

475 shell. Increasing aqueous $\mathrm{Mn}(\mathrm{II})$ shifts the XRD (001) and (002) peak positions to higher $2 \theta$

476 values (Figure EA3) with the (001) d-spacing, which corresponds to the interlayer spacing

477 between phyllomanganate sheets, decreasing by $0.03-0.05 \AA$. Additionally, XRD peaks in the

$478 \quad 35-70^{\circ} 2 \theta$ region shift systematically with $\mathrm{Mn}(\mathrm{II})$ addition (Figure EA3). This indicates that the 
479 addition of $\mathrm{Mn}$ (II) alters the sheet stacking or interlayer displacement, as has been invoked to

480 explain similar XRD peak shifts in past studies (Lanson et al., 2002; Drits et al., 2007). The

481 addition of 0.75 and $7.5 \mathrm{mM} \mathrm{Mn(II)}$ also leads to changes in low intensity XRD peaks at $\sim 22^{\circ} 2 \theta$

482 and in the $30-34^{\circ} 2 \theta$ region by shifting their positions and increasing their intensities,

483 respectively (Figure EA3). These peaks at $\sim 22^{\circ} 2 \theta$ and in the $30-34^{\circ} 2 \theta$ region are consistent

484 with the supercell reflections discussed above. These observations further support the conclusion

485 that the addition of $\mathrm{Mn}$ (II) alters phyllomanganate long range ordering.

486

$487 \quad p H 7$

$\mathrm{XRD}$ patterns show that the TriB sheet structure is much more stable at $\mathrm{pH} 7$ than at $\mathrm{pH}$

489 4, with little difference between the unreacted TriB and the sample aged in the absence of Mn(II)

490 (Figure 1). The EXAFS spectra, however, suggest that some aging-induced restructuring occurs

491 as the antinode at $8.1 \AA^{-1}$ is no longer split and shifted, as in unreacted TriB, although the

492 positive antinodes near at 6.8 and $9.2 \AA^{-1}$ are unchanged (Figure $2 \mathrm{H}$ ). Structural fitting of the

493 spectrum (Figure EA2) suggests that these changes may be the result of increased splitting in the

494 first $\mathrm{Mn}-\mathrm{Mn}$ shell and a lengthening of $\mathrm{Mn}-\mathrm{Mn}_{\mathrm{crnr}}$ (Table EA4). These results indicate that the

495 coordination environments of some Mn octahedra in the phyllomanganate sheet change and that

496 a portion of the capping atoms over vacancies are altered from $\mathrm{Mn}$ (III) to $\mathrm{Mn}$ (II). The AMOS

497 results are within error of the unreacted material, but the fraction of $\mathrm{Mn}(\mathrm{III})$ decreases while the

498 fractions of $\mathrm{Mn}(\mathrm{IV})$ and $\mathrm{Mn}(\mathrm{II})$ slightly increase (Table EA2) suggesting that some Mn(III) may

499 disproportionate, leading to more vacancy capping $\mathrm{Mn}$ (II) as indicated by the structural EXAFS

500 fits. These AMOS values also show that no redox interactions occurred between TriB and the

501 MES buffer, as those derived by XANES LCF are in agreement with those calculated by mass 
balance (Table 2).

The EXAFS spectrum of TriB aged in the presence of $0.75 \mathrm{mM}$ Mn(II) shows additional

504 changes to the 6.8 and $9.2 \AA^{-1}$ positive antinode (Figure $2 \mathrm{H}$ ). These antinodes are still much

505 broader than those in the $\mathrm{pH} 4$ system, but are consistent with a transition toward hexagonal

506 symmetry. A reduction in the splitting of the first $\mathrm{Mn}-\mathrm{O}$ shell occurs, and the $\mathrm{Mn}-\mathrm{Mn}_{\mathrm{crnr}}$ shell

507 increases substantially in coordination number, suggesting an increase of capping atoms over

508 vacancies (Table EA4). However, the minor feitknechtite component (Figure 1D), which consists

509 of a hexagonal Mn(III)-bearing sheet (Meldau et al., 1973), may cause destructive interference in

510 the EXAFS spectrum and it is thus uncertain whether the observed spectral changes correspond

511 to real structural alteration or are an artifact.

\section{DISCUSSION}

\section{4.1 Mechanism of Mn(II)-Induced Phyllomanganate Structural Changes}

These results indicate that in addition to adsorption, dissolved Mn(II)-phyllomanganate

516 interactions result in structural changes, which involve altered sheet symmetries and long-range

517 order within the sheet itself. The extent of these Mn(II)-induced structural alterations appear to

518 be dependent on both initial structural $\mathrm{Mn}(\mathrm{III})$ content and the $\mathrm{pH}$ of the solution. At $\mathrm{pH} 4$ in the

519 absence of $\mathrm{Mn}(\mathrm{II})$, some structural $\mathrm{Mn}$ is ejected from turbostratic phyllomanganate sheets,

520 which then adsorbs above vacancies. The addition of aqueous Mn(II), which also adsorbs above

521 vacancy sites, promotes the formation of a phyllomanganate with mixed sheet symmetries in the

$522 \delta-\mathrm{MnO}_{2}$ and $\mathrm{HexB}$ systems. In these cases, pseudo-orthogonal and hexagonal layers are

523 intermixed and the sheets are rotationally ordered to minimize repulsion between high valence

$524 \mathrm{Mn}$ in adjacent layers and Mn in the interlayer (Lanson et al., 2002). These changes also occur 
525 upon aging $\mathrm{HexB}$ at $\mathrm{pH} 4$ in the absence of $\mathrm{Mn}(\mathrm{II})$, concurrent with ejection of some structural

$526 \mathrm{Mn}$. Increasing $\mathrm{Mn}(\mathrm{II} / \mathrm{III})$ adsorption over vacancies may enhance electrostatic repulsion with

527 layer Mn(IV) in adjacent sheets, which would promote rotationally ordered stacking. In addition,

$528 \mathrm{Mn}$ (II) adsorption followed by comproportionation forms $\mathrm{Mn}$ (III) in the phyllomanganate sheet,

529 promoting a change from hexagonal to pseudo-orthogonal layer symmetry. These effects of

$530 \mathrm{Mn}(\mathrm{II})$ addition appear to promote long range ordering in the plane of the phyllomanganate

531 sheets, forming a supercell. Sheet-parallel ordering of vacancy sites capped by adsorbed Mn at

532 repeat distances greater than the unit cell size or ordering of pseudo-orthogonal and hexagonal

533 domains within the sheets could generate the observed supercell. Sheet restructuring only occurs

534 in samples with AMOS $<\sim 3.8$ containing $10-15$ mol.\% Mn(III), suggesting that a threshold

$535 \mathrm{Mn}(\mathrm{III})$ content is required to induce the observed structural changes. This hypothesized Mn(III)

536 threshold may originate because changes in sheet symmetry and ordering of vacancy capping

537 atoms likely increases with increasing Mn(III) content.

538 The distinct behavior of TriB at $\mathrm{pH} 4$ results from extensive $\mathrm{Mn}(\mathrm{III})$ disproportionation

539 dominating over other processes. This disproportionation relaxes Jahn-Teller-induced sheet

540 strain and leads to the formation of a hexagonally-symmetric material. The hexagonal sheet

541 symmetry at $\mathrm{pH} 4$ is still observed with the addition of $\mathrm{Mn}$ (II). These results indicate that the

542 amount of $\mathrm{Mn}$ (II) added is inadequate to promote $\mathrm{Mn}(\mathrm{II})-\mathrm{Mn}$ (IV) comproportionation, which

543 favors orthogonal sheet symmetry, over disproportionation.

544 Structural changes are much more muted at $\mathrm{pH} 7$ following aging in the absence and

545 presence of $\mathrm{Mn}(\mathrm{II}) . \delta-\mathrm{MnO}_{2}$ sheet stacking increases upon addition of $\mathrm{Mn}$ (II), while in the HexB

546 system, aqueous Mn(II) does not appear to alter the manganese oxide structure, restricting its

547 interaction to adsorption over vacant sites. TriB showed minor changes in the phyllomanganate 
548 sheet and far less disproportionation than at $\mathrm{pH} 4$, with $\mathrm{Mn}$ (III) being more stable at this $\mathrm{pH}$

549 (Mandernack et al., 1995). We hypothesize that phyllomanganates with larger numbers of

550 vacancies (i.e., $\delta-\mathrm{MnO}_{2}$ ) may exhibit greater structural changes (barring phase transformations)

551 upon addition of aqueous $\mathrm{Mn}(\mathrm{II})$ at $\mathrm{pH} 7$ as these are the sites where $\mathrm{Mn}$ (II) reacts with the

552 mineral phase. Feitknechtite precipitation at higher Mn(II) loadings is consistent with substantial

553 prior research on such phase transformations, which likely involve $\mathrm{pH}$-dependent $\mathrm{Mn}(\mathrm{II})-\mathrm{Mn}$ (IV)

554 comproportionation reactions (Elzinga, 2011; Lefkowitz et al., 2013).

555

$556 \quad 4.2$ Comparison to Prior Work

557 4.2.1 Aging Induced Changes to Phyllomanganate Structures

558 Previous research (Lanson et al., 2000; Manceau et al., 2013) has found that

559 phyllomanganate sheets undergo structural changes under acidic conditions in the absence of

$560 \mathrm{Mn}(\mathrm{II})$ that are consistent with those observed in the current study. High-energy X-ray scattering

561 and pair distribution function analysis demonstrates that structural Mn migrates into the

562 interlayers in $\delta-\mathrm{MnO}_{2}$ upon equilibration at low $\mathrm{pH}$ (Manceau et al., 2013). This results in

563 increased vacancy content and the formation of a supercell either through long range ordering of

564 sheet vacancies or ordering of interlayer Mn. In the current study, we also find that some layer

$565 \mathrm{Mn}$ is ejected from $\delta-\mathrm{MnO}_{2}$ sheets after aging at $\mathrm{pH} 4$, but evidence of the formation of a

566 supercell only appears with the addition of $\mathrm{Mn}(\mathrm{II})$ to the $\delta-\mathrm{MnO}_{2}$ system. However, we do find

567 that a supercell may form in HexB aged at $\mathrm{pH} 4$ in the absence of $\mathrm{Mn}(\mathrm{II})$, possibly because this

568 sample exceeds our hypothesized Mn(III) threshold for such restructuring. Previous research on

569 the structures of Na-birnessite [a triclinic birnessite (Post et al., 2002)] observed that the

570 phyllomanganate sheet transitioned towards hexagonal symmetry with increasing acidity (Drits 
571 et al., 1997; Silvester et al., 1997; Lanson et al., 2000), consistent with our observation that TriB

572 maintains its pseudo-orthogonal sheets after aging at $\mathrm{pH} 7$ but forms hexagonal sheets at $\mathrm{pH} 4$.

573 One recent study, however, observed that TriB partially transforms to hexagonal H-birnessite at

$574 \mathrm{pH} 7$ in solutions containing $20 \mathrm{mM}$ MES or HEPES buffers and in unbuffered solutions after 14

575 days (Ling et al., 2015). This distinct outcome compared to the present study and prior research

576 (Drits et al., 1997; Silvester et al., 1997; Lanson et al., 2000) is of unclear origin. Substantial

577 differences in the mineral to water ratio, concentration of buffers that may reduce manganese

578 oxides (Elzinga and Kustka, 2015), and ionic strength among these experiments all may

579 contribute to the contrasting observed stability of the triclinic birnessite structure.

\subsubsection{Mn(II) Induced Changes to Phyllomanganate Structures}

Although most studies of interactions between dissolved $\mathrm{Mn}(\mathrm{II})$ and solid manganese

583 oxide in abiotic systems have largely focused on phase transformation behaviors (Elzinga, 2011;

584 Lefkowitz et al., 2013; Elzinga and Kustka, 2015), some have indicated that Mn(II) can affect

585 phyllomanganate sheet structures (Bargar et al., 2005; Zhu et al., 2010a; Lefkowitz et al., 2013),

586 inducing changes similar to those observed in the present study. Previous research demonstrated

587 that $\mathrm{Mn}(\mathrm{II})$ adsorbs above vacancies in a biogenic, hexagonally-symmetric manganese oxide but

588 that interlayer Mn decreases with increasing $\mathrm{pH}$, indicating that $\mathrm{Mn}(\mathrm{II})$ oxidizes via

$589 \mathrm{Mn}(\mathrm{II})-\mathrm{Mn}(\mathrm{IV})$ comproportionation and enters the phyllomanganate sheet as Mn(III) (Zhu et al.,

590 2010a). The fraction of phyllomanganates with orthogonal structures was also found to increase

591 with time during reaction of $\delta-\mathrm{MnO}_{2}$ with $100 \mu \mathrm{M}$ dissolved $\mathrm{Mn}(\mathrm{II})$ at $\mathrm{pH} 8$ (Bargar et al., 2005).

592 Recent research also finds that under oxic conditions, $\delta-\mathrm{MnO}_{2}$ progressively transitions to a

593 triclinic birnessite type structure upon aging with $\mathrm{Mn}(\mathrm{II})$ at $\mathrm{pH} \geq 8$, with increasing 
594 transformations observed with increasing $\mathrm{pH}$ (Zhao et al., 2016). No structural transformations

595 were observed at $\mathrm{pH} 7$, consistent with the current study.

596 As in prior studies (Bargar et al., 2005; Elzinga, 2011; Lefkowitz et al., 2013), the

597 addition of substantial $\mathrm{Mn}(\mathrm{II})$ to all mineral systems at $\mathrm{pH} 7$ resulted in the precipitation of

598 feitknechtite. These samples have measured AMOS values near 3.20 (Table 2) and XRD patterns

599 indicative of a mixture of phases, dominated by feitknechtite. Our experiments were conducted

600 with aqueous $\mathrm{Mn}$ (II) to solid Mn oxide ratios lower (3 mmol Mn(II) $\mathrm{g}^{-1}$ ) than those previously

601 required to precipitate feitknechtite at $\mathrm{pH} 7$ under anoxic conditions $\left(8 \mathrm{mmol} \mathrm{Mn}\right.$ (II) $\mathrm{g}^{-1}$, with no

602 feitknechtite precipitation at 2-6 mmol Mn(II) $\mathrm{g}^{-1}$ ) (Lefkowitz et al., 2013) and the solids in the

603 present work have surface areas similar to or larger than those used in the previous studies. We

604 hypothesize that the formation of feitknechtite at these lower Mn(II) contents is related to the

605 longer reaction times in this current study ( 25 versus 8 days). We also observed minor

606 feitknechtite precipitation at $\mathrm{pH} 7$ with TriB at low initial $\mathrm{Mn}$ (II) concentrations $(0.75 \mathrm{mM}$ initial

$\left.607 \mathrm{Mn}(\mathrm{II}) ; 0.3 \mathrm{mmol} \mathrm{Mn}(\mathrm{II}) \mathrm{g}^{-1}\right)$. This indicates that the initial structural Mn(III) content is an

608 important factor in $\mathrm{Mn}(\mathrm{II})$-induced phase transformations to $\mathrm{MnOOH}$ phases.

\section{$610 \quad 4.3$ Relevance to Environmental and Geologic Systems}

611 The results of this study suggest that phyllomanganates in natural systems interact with

612 dissolved $\mathrm{Mn}(\mathrm{II})$ primarily through adsorption and comproportionation-disproportionation

613 reactions, resulting in subtle alterations to phyllomanganate sheet structures. Although dissolved

$614 \mathrm{Mn}(\mathrm{II})$ concentrations exhibit spatial and temporal variations in natural systems, these are often

615 lower than those observed to induce phase transformations at circumneutral $\mathrm{pH}$ (Graybeal and

616 Heath, 1984; Rajendran et al., 1992; Burdige, 1993; Van Cappellen et al., 1998; Tebo et al., 
617 2004; Tebo et al., 2005; Pakhomova et al., 2007). Thus, abiotic Mn(II)-phyllomanganate

618 interactions that occur in these systems likely involve $\mathrm{Mn}(\mathrm{II})$ adsorption and restructuring of

619 phyllomanganate sheets, depending on the $\mathrm{pH}$ of the system.

620 These Mn(II)-induced structural changes, as well as capping of vacancy sites, could cause

621 a reduction in overall reactivity of manganese oxides and in trace metal sorption. Because the

622 structural changes induced by aqueous $\mathrm{Mn}$ (II) results from a decreased Mn oxidation state in the

623 phyllomanganate sheet, $\mathrm{Mn}(\mathrm{II})$ uptake may change phyllomanganate reactivity towards redox-

624 active adsorbates. The adsorption of $\mathrm{Mn}(\mathrm{II})$ and subsequent restructuring of phyllomanganate

625 sheets observed at low $\mathrm{pH}$ suggests that $\mathrm{Mn}$ (II) may decrease trace metal sorption in acidic

626 systems by removing reactive sites. In environments at circumneutral to alkaline $\mathrm{pH}$, such as

627 marine sediments and suboxic soils, the interaction of dissolved Mn(II) with trace metals on

628 phyllomanganate surfaces may be limited to competitive adsorption effects, such as capping

629 vacancies and thus decreasing the number of surface sites available for trace metal adsorption

630 (Toner et al., 2006; Peacock and Sherman, 2007; Manceau et al., 2007b; Peacock, 2009; Zhu et

631 al., 2010b) and later incorporation (Peacock and Sherman, 2007). However, natural waters have

632 more complex major cation compositions than the $\mathrm{NaCl}$ fluid studied here, and the effects of

633 fluid composition on Mn(II)-phyllomanganate interactions is unknown. Past work shows that

$634 \mathrm{Ca}^{2+}$ promotes structural transformations of phyllomanganate to pseudo-orthogonally symmetric

635 sheets (Webb et al., 2005b). It is thus possible that $\mathrm{Ca}^{2+}$ and other common cations in natural

636 waters may enhance Mn(II)-induced phyllomanganate structural changes and any associated

637 effects on trace metal binding. These implications are consistent with recent observations from a

638 cave system, where phyllomanganates formed in fluids with higher dissolved Mn(II)

639 concentrations have lower trace metal contents than those produced in low-Mn(II) settings 
640 (Frierdich and Catalano, 2012). The results of the present study show that dissolved Mn(II)

641 influences phyllomanganate sheet structures, potentially altering the sorption behavior and

642 reactivities of these minerals in natural systems, and that environmental conditions such as $\mathrm{pH}$

643 and fluid composition are the dominant controls on $\mathrm{Mn}$ (II)-induced structural changes.

647 Low-Temperature Geochemistry Program supported this research through Grant No.

648 EAR-1056480. Flynn was also supported by the NSF Graduate Research Fellowship program

649 through Grant No. DGE-1143954. The facilities and instruments maintained by the Nano

650 Research Facility at Washington University, supported by the NSF through Award No.

651 ECS-0335765, were used to conduct ICP-OES analyses. XRD patterns were collected with the

652 Bruker D8 Advance XRD instrument at Washington University in St. Louis, supported by the

653 NSF through Award No. EAR-1161543. The pH 7 MES-buffer and $\mathrm{pH} 4$ experiment XAFS

654 spectra in this study were collected at the DuPont-Northwestern-Dow Collaborative Access

655 Team (DND-CAT) located at Sector 5 of the Advanced Photon Source (APS). DND-CAT is

656 supported by Northwestern University, E.I. DuPont de Nemours \& Co., and The Dow Chemical

657 Company. The pH 7 XAFS spectra were collected at APS beamline 12-BM-B. The APS is a U.S.

658 Department of Energy (DOE) Office of Science User Facility operated for the DOE Office of

659 Science by Argonne National Laboratory under Contract No. DE-AC02-06CH11357. The

660 authors would particularly like to thank Qing Ma for his help in setting up and collecting XAFS

661 spectra at 5-BM-D and Sungsik Lee and Benjamin Reinhart for their support of data collection at 662 beamline 12-BM-B. 
665 This document contains information regarding MES buffer effects at $\mathrm{pH}$ 7. In addition, figures of

666 XANES spectra of Mn oxidation state standards, EXAFS data and fits, XRD patterns of TriB

667 aged at $\mathrm{pH} 4$, and XANES spectra and XRD patterns showing the impact of MES buffer on $\mathrm{pH} 7$

668 samples are included. Data regarding spectral fitting results for EXAFS measurements,

669 diffraction lines of manganese (hydr)oxides, and Langmuir isotherm parameters for Mn(II)

670 adsorption experiments are also listed. 


\section{REFERENCES}

Ankoudinov A. L. Relativistic Spin-dependent X-ray Absorption Theory, Ph.D. Thesis, University of Washington, 1996.

Bargar J. R., Fuller C. C., Marcus M. A., Brearley A. J., de la Rosa M. P., Webb S. M. and Caldwell W. A. (2009) Structural characterization of terrestrial microbial Mn oxides from Pinal Creek, AZ. Geochim. Cosmochim. Acta 73, 889-910.

Bargar J. R., Tebo B. M., Bergmann U., Webb S. M., Glatzel P., Chiu V. Q. and Villalobos M. (2005) Biotic and abiotic products of Mn(II) oxidation by spores of the marine Bacillus $s p$. strain SG-1. Am. Mineral. 90, 143-154.

Bargar J. R., Tebo B. M. and Villinski J. E. (2000) In situ characterization of Mn (II) oxidation by spores of the marine Bacillus sp. strain SG-1. Geochim. Cosmochim. Acta 64, 27752778.

Brindley G. W. and Brown G. (1980) Crystal structures of clay minerals and their X-ray identification. Mineralogical Society, London 361-410.

Burdige D. J. (1993) The biogeochemistry of manganese and iron reduction in marine sediments. Earth-Sci. Rev. 35, 249-284.

Canfield D. E., Thamdrup B. and Hansen J. W. (1993) The anaerobic degradation of organic matter in Danish coastal sediments: iron reduction, manganese reduction, and sulfate reduction. Geochim. Cosmochim. Acta 57, 3867-3885.

Clement B. G., Luther III G. W. and Tebo B. M. (2009) Rapid, oxygen-dependent microbial $\mathrm{Mn}(\mathrm{II})$ oxidation kinetics at sub-micromolar oxygen concentrations in the Black Sea suboxic zone. Geochim. Cosmochim. Acta 73, 1878-1889.

Dick G. J., Clement B. G., Webb S. M., Fodrie F. J., Bargar J. R. and Tebo B. M. (2009) Enzymatic microbial Mn(II) oxidation and Mn biooxide production in the Guaymas Basin deep-sea hydrothermal plume. Geochim. Cosmochim. Acta 73, 6517-6530.

Drits V. A., Lanson B., Bougerol-Chaillout C., Gorshkov A. I. and Manceau A. (2002) Structure of heavy-metal sorbed birnessite: Part 2. Results from electron diffraction. Am. Mineral. 87, 1646-1661.

Drits V. A., Lanson B. and Gaillot A. -C. (2007) Birnessite polytype systematics and identification by powder X-ray diffraction. Am. Mineral. 92, 771-788.

Drits V. A., Lanson B., Gorshkov A. I. and Manceau A. (1998) Substructure and superstructure of four-layer Ca-exchanged birnessite. Am. Mineral. 83, 97-118.

Drits V. A. and McCarty D. K. (1996) The nature of diffraction effects from illite and illitesmectite consisting of interstratified trans-vacant and cis-vacant 2:1 layers: A 
semiquantitative technique for determination of layer-type content. Am. Mineral. 81, 852863.

Drits V. A., Silvester E., Gorshkov A. I. and Manceau A. (1997) Structure of synthetic monoclinic Na-rich birnessite and hexagonal birnessite: I. Results from X-ray diffraction and selected-area electron diffraction. Am. Mineral. 82, 946-961.

Elzinga E. J. (2011) Reductive transformation of birnessite by aqueous Mn (II). Environ. Sci. Technol. 45, 6366-6372.

Elzinga E. J. and Kustka A. B. (2015) A Mn-54 radiotracer study of Mn isotope solid-liquid exchange during reductive transformation of vernadite $(\delta-\mathrm{MnO} 2)$ by aqueous $\mathrm{Mn}$ (II). Environ. Sci. Technol. 49, 4310-4316.

Emerson S., Kalhorn S., Jacobs L., Tebo B. M., Nealson K. H. and Rosson R. A. (1982) Environmental oxidation rate of manganese(II): bacterial catalysis. Geochim. Cosmochim. Acta 46, 1073-1079.

Friedl G., Wehrli B. and Manceau A. (1997) Solid phases in the cycling of manganese in eutrophic lakes: New insights from EXAFS spectroscopy. Geochim. Cosmochim. Acta 61, 275-290.

Frierdich A. J. and Catalano J. G. (2012) Distribution and speciation of trace elements in iron and manganese oxide cave deposits. Geochim. Cosmochim. Acta 91, 240-253.

Golden D. C., Chen C. C. and Dixon J. B. (1987) Transformation of birnessite to buserite, todorokite, and manganite under mild hydrothermal treatment. Clays Clay Miner. 35, 271-280.

Golden D. C., Dixon J. B. and Chen C. C. (1986) Ion exchange, thermal transformations, and oxidizing properties of birnessite. Clays Clay Miner. 34, 511-520.

Grangeon S., Lanson B., Miyata N., Tani Y. and Manceau A. (2010) Structure of nanocrystalline phyllomanganates produced by freshwater fungi. Am. Mineral. 95, 1608-1616.

Grangeon S., Manceau A., Guilhermet J., Gaillot A. C., Lanson M. and Lanson B. (2012) Zn sorption modifies dynamically the layer and interlayer structure of vernadite. Geochim. Cosmochim. Acta 85, 302-313.

Graybeal A. L. and Heath G. R. (1984) Remobilization of transition metals in surficial pelagic sediments from the eastern Pacific. Geochim. Cosmochim. Acta 48, 965-975.

Hinkle M. A. G., Wang Z., Giammar D. E. and Catalano J. G. (2015) Interaction of Fe(II) with phosphate and sulfate on iron oxide surfaces. Geochim. Cosmochim. Acta 158, 130-146.

Krumbein W. E. and Jens K. (1981) Biogenic rock varnishes of the Negev Desert (Israel) and ecological study of iron and magnanese transformation by cyanobacteria and fungi. Oceologia 50, 25-38. 
Lanson B., Drits V. A., Gaillot A. -C., Silvester E., Plançon A. and Manceau A. (2002) Structure of heavy-metal sorbed birnessite: Part 1. Results from X-ray diffraction. Am. Mineral. 87, 1631-1645.

Lanson B., Drits V. A., Silvester E. and Manceau A. (2000) Structure of H-exchanged hexagonal birnessite and its mechanism of formation from Na-rich monoclinic buserite at low $\mathrm{pH}$. Am. Mineral. 85, 826-838.

Lanson B., Marcus M. A., Fakra S., Panfili F., Geoffroy N. and Manceau A. (2008) Formation of $\mathrm{Zn}-\mathrm{Ca}$ phyllomanganate nanoparticles in grass roots. Geochim. Cosmochim. Acta 72, 2478-2490.

Lefkowitz J. P., Rouff A. A. and Elzinga E. J. (2013) Influence of pH on the reductive transformation of birnessite by aqueous Mn(II). Environ. Sci. Technol. 47, 10364-10371.

Ling F. T., Heaney P. J., Post J. E. and Gao X. (2015) Transformations from triclinic to hexagonal birnessite at circumneutral $\mathrm{pH}$ induced through $\mathrm{pH}$ control by common biological buffers. Chem. Geol. 416, 1-10.

Lopano C. L., Heaney P. J., Post J. E., Hanson J. and Komarneni S. (2007) Time-resolved structural analysis of $\mathrm{K}$ - and Ba-exchange reactions with synthetic Na-birnessite using synchrotron X-ray diffraction. Am. Mineral. 92, 380-387.

Luther G. W. (2010) The role of one- and two-electron transfer reactions in forming thermodynamically unstable intermediates as barriers in multi-electron redox reactions. Aquatic Geochemistry 16, 395-420.

Manceau A., Kersten M., Marcus M. A., Geoffroy N. and Granina L. (2007a) Ba and Ni speciation in a nodule of binary Mn oxide phase composition from Lake Baikal. Geochim. Cosmochim. Acta 71, 1967-1981.

Manceau A., Lanson M. and Geoffroy N. (2007b) Natural speciation of Ni, Zn, Ba, and As in ferromanganese coatings on quartz using X-ray fluorescence, absorption, and diffraction. Geochim. Cosmochim. Acta 71, 95-128.

Manceau A., Marcus M. A. and Grangeon S. (2012) Determination of Mn valence states in mixed-valent manganates by XANES spectroscopy. Am. Mineral. 97, 816-827.

Manceau A., Marcus M. A., Grangeon S., Lanson M., Lanson B., Gaillot A. -C., Skanthakumar S. and Soderholm L. (2013) Short-range and long-range order of phyllomanganate nanoparticles determined using high-energy X-ray scattering. J. Appl. Crystallogr. 46, 193-209.

Manceau A., Tommaseo C., Rihs S., Geoffroy N., Chateigner D., Schlegel M., Tisserand D., Marcus M. A., Tamura N. and Chen Z. -S. (2005) Natural speciation of Mn, Ni, and Zn at the micrometer scale in a clayey paddy soil using X-ray fluorescence, absorption, and diffraction. Geochim. Cosmochim. Acta 69, 4007-4034. 
Mandernack K. W., Post J. E. and Tebo B. M. (1995) Manganese mineral formation by bacterial spores of a marine Bacillus, strain SG-1: Evidence for the direct oxidation of $\mathrm{Mn}$ (II) to Mn(IV). Geochim. Cosmochim. Acta 59, 4393-4408.

Marcus M. A., Manceau A. and Kersten M. (2004) Mn, Fe, Zn and As speciation in a fastgrowing ferromanganese marine nodule. Geochim. Cosmochim. Acta 68, 3125-3136.

McKenzie R. M. (1980) The adsorption of lead and other heavy metals on oxides of manganese and iron. Soil Research 18, 61-73.

McKeown D. A. and Post J. E. (2001) Characterization of manganese oxide mineralogy in rock varnish and dendrites using X-ray absorption spectroscopy. Am. Mineral. 86, 701-713.

Meldau R., Newesely H. and Strunz H. (1973) Zur Kristallchemie von Feitknechtit, $\beta$-MnOOH. Naturwissenschaften 60, 387-387.

Morgan J. J. (2005) Kinetics of reaction between $\mathrm{O}_{2}$ and $\mathrm{Mn}$ (II) species in aqueous solutions. Geochim. Cosmochim. Acta 69, 35-48.

Morgan J. J. and Stumm W. (1964) Colloid-chemical properties of manganese dioxide. J. Coll. Sci. 19, 347-359.

Murray J. W., Balistrieri L. S. and Paul B. (1984) The oxidation state of manganese in marine sediments and ferromanganese nodules. Geochim. Cosmochim. Acta 48, 1237-1247.

Nealson K. H., Tebo B. M. and Rosson R. A. (1988) Occurrence and mechanisms of microbial oxidation of manganese. Adv. Appl. Microbiol. 33, 2027-2035.

Nelson Y. M. and Lion L. W. (2003) Formation of biogenic manganese oxides and their influence on the scavenging of toxic trace elements. Geochemical and Hydrological Reactivity of Heavy Metals in Soils. CRC Press 200, 169-186.

Newville M. (2001) IFEFFIT: interactive EXAFS analysis and FEFF fitting. J. Synchrotron Radiat. 8, 322-324.

Pakhomova S. V., Hall P. O., Kononets M. Y., Rozanov A. G., Tengberg A. and Vershinin A. V. (2007) Fluxes of iron and manganese across the sediment--water interface under various redox conditions. Mar. Chem. 107, 319-331.

Peacock C. L. (2009) Physiochemical controls on the crystal-chemistry of Ni in birnessite: Genetic implications for ferromanganese precipitates. Geochim. Cosmochim. Acta 73, 3568-3578.

Peacock C. L. and Sherman D. M. (2007) Crystal-chemistry of Ni in marine ferromanganese crusts and nodules. Am. Mineral. 92, 1087-1092.

Post J. E. (1999) Manganese oxide minerals: Crystal structures and economic and environmental significance. Proc. Natl. Acad. Sci. U. S. A. 96, 3447-3454. 
Post J. E. and Appleman D. E. (1988) Chalcophanite, $\mathrm{ZnMn}_{3} \mathrm{O}_{7}-3 \mathrm{H}_{2} \mathrm{O}$ : New crystal-structure determinations. Am. Mineral. 73, 1401-1404.

Post J. E., Heaney P. J. and Hanson J. (2002) Rietveld refinement of a triclinic structure for synthetic Na-birnessite using synchrotron powder diffraction data. Powder Diffr. 17, 218 221.

Post J. E. and Veblen D. R. (1990) Crystal structure determinations of synthetic sodium, magnesium, and potassium birnessite using TEM and the Rietveld method. Am. Mineral. 75, 477-489.

Post J. E., Von Dreele R. B. and Buseck P. R. (1982) Symmetry and cation displacements in hollandites: structure refinements of hollandite, cryptomelane and priderite. Acta Crystallogr., Sect. B: Struct. Sci. 38, 1056-1065.

Rajendran A., Kumar M. D. and Bakker J. F. (1992) Control of manganese and iron in Skagerrak sediments (northeastern North Sea). Chem. Geol. 98, 111-129.

Ravel B. and Newville M. (2005) ATHENA, ARTEMIS, HEPHAESTUS: data analysis for Xray absorption spectroscopy using IFEFFIT. J. Synchrotron Radiat. 12, 537-541.

Santelli C. M., Webb S. M., Dohnalkova A. C. and Hansel C. M. (2011) Diversity of Mn oxides produced by Mn(II)-oxidizing fungi. Geochim. Cosmochim. Acta 75, 2762-2776.

Saratovsky I., Wightman P. G., Pasten P. A., Gaillard J. F. and Poeppelmeier K. R. (2006) Manganese oxides: Parallels between abiotic and biotic structures. J. Am. Chem. Soc. 128, 11188-11198.

Shimmield G. B. and Price N. B. (1986) The behaviour of molybdenum and manganese during early sediment diagenesis off shore Baja California, Mexico. Mar. Chem. 19, 261-280.

Silvester E., Manceau M. and Drits V. A. (1997) Structure of synthetic monoclinic Na-rich birnessite and hexagonal birnessite: II. Results from chemical studies and EXAFS spectroscopy. Am. Mineral. 82, 962-978.

Tan H., Zhang G., Heaney P. J., Webb S. M. and Burgos W. D. (2010) Characterization of manganese oxide precipitates from Appalachian coal mine drainage treatment systems. Appl. Geochem. 25, 389-399.

Tebo B. M. (1991) Manganese (II) oxidation in the suboxic zone of the Black Sea. Deep-Sea Res 38, S883-S905.

Tebo B. M., Bargar J. R., Clement B. G., Dick G. J., Murray K. J., Parker D., Verity R. and Webb S. M. (2004) Biogenic manganese oxides: Properties and mechanisms of formation. Annu. Rev. Earth Pl. Sc. 32, 287-328. 
Tebo B. M., Ghiorse W. C., van Waasbergen L. G., Siering P. L. and Caspi R. (1997) Bacterially mediated mineral formation; insights into manganese (II) oxidation from molecular genetic and biochemical studies. Rev. Mineral. Geochem. 35, 225-266.

Tebo B. M., Johnson H. A., McCarthy J. K. and Templeton A. S. (2005) Geomicrobiology of manganese(II) oxidation. Trends Microbiol. 13, 421-428.

Toner B., Manceau A., Webb S. M. and Sposito G. (2006) Zinc sorption by biogenic hexagonal birnessite particles within a hydrated bacterial biofilm. Geochim. Cosmochim. Acta 70, .

Tu S., Racz G. J. and Goh T. B. (1994) Transformations of synthetic birnessite as affected by $\mathrm{pH}$ and manganese concentration. Clays Clay Miner. 42, 321-330.

Van Cappellen P., Viollier E., Roychoudhury A., Clark L., Ingall E., Lowe K. and Dichristina T. (1998) Biogeochemical cycles of manganese and iron at the oxic-anoxic transition of a stratified marine basin (Orca Basin, Gulf of Mexico). Environ. Sci. Technol. 32, 29312939.

Viani A., Gualtieri A. F. and Artioli G. (2002) The nature of disorder in montmorillonite by simulation of X-ray powder patterns. Am. Mineral. 87, 966-975.

Villalobos M., Lanson B., Manceau A., Toner B. and Sposito G. (2006) Structural model for the biogenic Mn oxide produced by Pseudomonas putida. Am. Mineral. 91, 489-502.

Villalobos M., Toner B., Bargar J. R. and Sposito G. (2003) Characterization of the manganese oxide produced by pseudomonas putida strain MnB1. Geochim. Cosmochim. Acta 67, 2649-2662.

Von Langen P. J., Johnson K. S., Coale K. H. and Elrod V. A. (1997) Oxidation kinetics of manganese (II) in seawater at nanomolar concentrations. Geochim. Cosmochim. Acta 61, 4945-4954.

Webb S. M. (2005) SIXPack: A Graphical User Interface for XAS Analysis using IFEFFIT. Phys. Scripta T115, 1011-1014.

Webb S. M., Tebo B. M. and Bargar J. R. (2005a) Structural characterization of biogenic Mn oxides produced in seawater by the marine bacillus sp. strain SG-1. Am. Mineral. 90, 1342-1357.

Webb S. M., Tebo B. M. and Bargar J. R. (2005b) Structural influences of sodium and calcium ions on the biogenic manganese oxides produced by the marine Bacillus sp., strain SG-1. Geomicrobiol. J. 22, 181-193.

Wehrli B., Friedl G. and Manceau A. Reaction rates and products of manganese oxidation at the sediment-water interface, In Advances in Chemistry, 1995; pp. 111-134. 
Yu Q., Sasaki K., Tanaka K., Ohnuki T. and Hirajima T. (2012) Structural factors of biogenic birnessite produced by fungus Paraconiothyrium sp. WL-2 strain affecting sorption of $\mathrm{Co}^{2+}$. Chem. Geol. 310-311, 106-113.

Zhao H., Zhu M., Li W., Elzinga E. J., Villalobos M., Liu F., Zhang J., Feng X. and Sparks D. L. (2016) Redox reactions between Mn(II) and hexagonal birnessite change its layer symmetry. Environ. Sci. Technol. 50, 1750-8.

Zhu M., Ginder-Vogel M., Parikh S. J., Feng X. H. and Sparks D. L. (2010a) Cation effects on the layer structure of biogenic Mn-oxides. Environ. Sci. Technol. 44, 4465-4471.

Zhu M., Ginder-Vogel M. and Sparks D. L. (2010b) Ni(II) sorption on biogenic Mn-oxides with varying Mn octahedral layer structure. Environ. Sci. Technol. 44, 4472-4478. 
Table 1. Structural $\mathrm{Mn}$ and $\mathrm{Na}$ content and relative amounts of initial dissolved $\mathrm{Mn}^{2+}$ and solid $\mathrm{Mn}^{4+}$ in the 25 day aging experiments.

\begin{tabular}{|c|c|c|c|c|c|}
\hline Mineral & $\begin{array}{c}\text { Moles } \mathrm{Mn}_{(\mathrm{s})} \\
\text { per g mineral }\end{array}$ & $\begin{array}{l}\text { Moles Na per } \mathbf{g} \\
\text { mineral }\end{array}$ & $\begin{array}{l}\text { Na:Mn } \\
\text { (mol:mol) }\end{array}$ & $\begin{array}{c}\text { Initial } \\
\mathrm{Mn}^{2+}{ }_{(\mathrm{aq})}: \mathrm{Mn}^{4+}{ }_{(\mathrm{s})} \\
(\mathrm{mol}: \mathrm{mol}) \\
\mathbf{0 . 7 5} \mathbf{~ m M ~ M n ( I I )}\end{array}$ & $\begin{array}{c}\text { Initial } \\
\mathrm{Mn}_{(\mathrm{aq})}: \mathrm{Mn}^{4+}(\mathrm{s}) \\
(\mathrm{mol}: \mathrm{mol}) \\
7.5 \mathrm{mM} \mathrm{Mn}(\mathrm{II})\end{array}$ \\
\hline $\bar{\delta}-\mathrm{MnO}_{2}$ & 0.0067 & 0.0011 & 0.16 & 0.045 & 0.450 \\
\hline HexB & 0.0083 & 0.0002 & 0.02 & 0.042 & 0.452 \\
\hline TriB & 0.0097 & 0.0027 & 0.28 & 0.054 & 0.543 \\
\hline
\end{tabular}

Table 2. Properties of synthesized and reacted phyllomanganates, including the reaction conditions and final solution concentrations for the aging experiments.

\begin{tabular}{|c|c|c|c|c|c|c|c|}
\hline Sample ID & $\begin{array}{c}\text { Mn } \\
\text { Oxide }\end{array}$ & pH & $\begin{array}{c}{[\mathbf{M n}(\mathrm{II})]_{\text {initial }}} \\
(\mathbf{m M})\end{array}$ & $\begin{array}{l}\text { XANES } \\
\text { AMOS }^{a}\end{array}$ & MB AMOS ${ }^{b}$ & $\begin{array}{c}{[\mathrm{Mn}]_{\text {soln }}} \\
(\mathrm{mM})\end{array}$ & $\begin{array}{c}{[\mathrm{Mn}]_{\text {ads }}} \\
\left(\mathrm{mmol} \mathrm{g}^{-1}\right)\end{array}$ \\
\hline \multicolumn{8}{|l|}{ Unreacted: } \\
\hline Synth $\delta$ & $\delta-\mathrm{MnO}_{2}$ & & & 3.99 & & & \\
\hline SynthHB & HexB & & & 3.80 & & & \\
\hline SynthTB & TriB & & & 3.57 & & & \\
\hline \multicolumn{8}{|l|}{ Aging Samples: } \\
\hline $4 \delta$ no & $\delta-\mathrm{MnO}_{2}$ & 4 & 0 & 3.93 & 3.99 & $0.012 \pm 0.001$ & $-0.005^{c}$ \\
\hline $4 \delta$ low & $\delta-\mathrm{MnO}_{2}$ & 4 & 0.75 & 3.82 & 3.91 & $\mathrm{BDL}^{d}$ & 0.30 \\
\hline 48high & $\delta-\mathrm{MnO}_{2}$ & 4 & 7.5 & 3.67 & 3.68 & $4.4 \pm 0.1$ & 1.24 \\
\hline $7 \delta$ no & $\delta-\mathrm{MnO}_{2}$ & 7 & 0 & 3.98 & 3.99 & BDL & - \\
\hline 78low & $\delta-\mathrm{MnO}_{2}$ & 7 & 0.75 & 3.94 & 3.91 & BDL & 0.30 \\
\hline 78high & $\delta-\mathrm{MnO}_{2}$ & 7 & 7.5 & 3.22 & 3.38 & BDL & 3.00 \\
\hline 4HexBno & HexB & 4 & 0 & 3.79 & 3.80 & BDL & - \\
\hline 4HexBlow & HexB & 4 & 0.75 & 3.64 & 3.77 & $0.48 \pm 0.02$ & 0.11 \\
\hline 4HexBhigh & HexB & 4 & 7.5 & $--^{e}$ & 3.73 & $6.8 \pm 0.2$ & 0.28 \\
\hline 7HexBno & HexB & 7 & 0 & 3.79 & 3.80 & BDL & - \\
\hline 7HexBlow & HexB & 7 & 0.75 & 3.72 & 3.73 & $\mathrm{BDL}$ & 0.30 \\
\hline 7HexBhigh & HexB & 7 & 7.5 & 3.21 & 3.27 & BDL & 3.00 \\
\hline 4TriBno & TriB & 4 & 0 & 3.67 & 3.61 & $0.43 \pm 0.01$ & -0.17 \\
\hline 4TriBlow & TriB & 4 & 0.75 & 3.63 & 3.63 & $0.88 \pm 0.03$ & -0.05 \\
\hline 4TBhigh & TriB & 4 & 7.5 & 3.60 & 3.60 & $6.70 \pm 0.08$ & 0.32 \\
\hline 7TriBno & TriB & 7 & 0 & 3.60 & 3.57 & BDL & - \\
\hline 7TriBlow & TriB & 7 & 0.75 & 3.53 & 3.51 & BDL & 0.30 \\
\hline 7TriBhigh & TriB & 7 & 7.5 & 3.11 & 3.10 & BDL & 3.00 \\
\hline
\end{tabular}

${ }^{a}$ Average manganese oxidation state (AMOS) determined by XANES. Estimated accuracy is approximately 0.04 v.u. (Manceau et al., 2012)

${ }^{b}$ AMOS predicted by mass balance (MB).

${ }^{c}$ Negative value indicates net release of $\mathrm{Mn}(\mathrm{II})$ to solution.

${ }^{d}$ BDL denotes below detection limit $(0.006 \mathrm{mM})$.

${ }^{e}$ No XANES data is presented for this sample because it was damaged prior to analysis. 


\section{FIGURE CAPTIONS}

Figure 1. XRD patterns of unreacted manganese oxides (A) and of $\delta-\mathrm{MnO} 2(\mathrm{~B}), \mathrm{HexB}(\mathrm{C})$, and TriB (D) after aging for 25 days in the absence or presence of dissolved Mn(II); see Table 2 for specific conditions. In (B-D), patterns of the unreacted samples (black) and samples reacted without $\mathrm{Mn}(\mathrm{II})$ (see legend) are overplotted by the pattern of the corresponding sample reacted with $\mathrm{Mn}$ (II) (see legend). The red asterisk in (D) denotes a peak corresponding to feitknechtite. The vertical dashed line in (D) demarcates an intensity scale change from $1 \times$ to $8 \times$ intensity.

Figure 2. Mn K-edge XAFS spectra of unreacted and reacted $\delta-\mathrm{MnO}_{2}(\mathrm{~A}-\mathrm{C}), \mathrm{HexB}(\mathrm{D}-\mathrm{F})$, and TriB (G-I); see Table 2 for specific conditions. XANES spectra (A,D,G), EXAFS spectra $(\mathrm{B}, \mathrm{E}, \mathrm{H})$, or Fourier transform $(\mathrm{C}, \mathrm{F}, \mathrm{I})$ data of the aged samples are overplotted with one another for each $\mathrm{pH}$ set. Vertical blue lines denote diagnostic features at $6553 \mathrm{eV}$ in the XANES spectra, 6.8, 8.1, and 9.2 $\AA^{-1}$ in the EXAFS spectrum, and 3.0 and 5.2 $\AA$ in the EXAFS Fourier transform; the vertical black dashed line indicates the white line energy of unreacted triclinic birnessite. XAFS spectra of samples reacted with $7.5 \mathrm{mM} \mathrm{Mn(II)} \mathrm{at} \mathrm{pH} 7$ appear in Figure 4.

Figure 3. (A) $\mathrm{Mn}$ (II) adsorption isotherms at $\mathrm{pH} 4$ after 2 days of reaction. Lines represent Langmuir isotherm fits to the data (see Table EA1). (B) Mn(II) uptake (points) onto phyllomanganates after 25 days of reaction at $\mathrm{pH} 4$ compared to Langmuir isotherm curves determined from the 2 day $\mathrm{Mn}(\mathrm{II})$ adsorption isotherm measurements.

Figure 4. XRD patterns (A) and XANES spectra (B) of phyllomanganates reacted for 25 days with $7.5 \mathrm{mM} \mathrm{Mn}(\mathrm{II})$. Peaks corresponding to feitknechtite in XRD are denoted by red asterisks. Dotted lines represent XANES spectra of the corresponding unreacted phyllomanganate. 

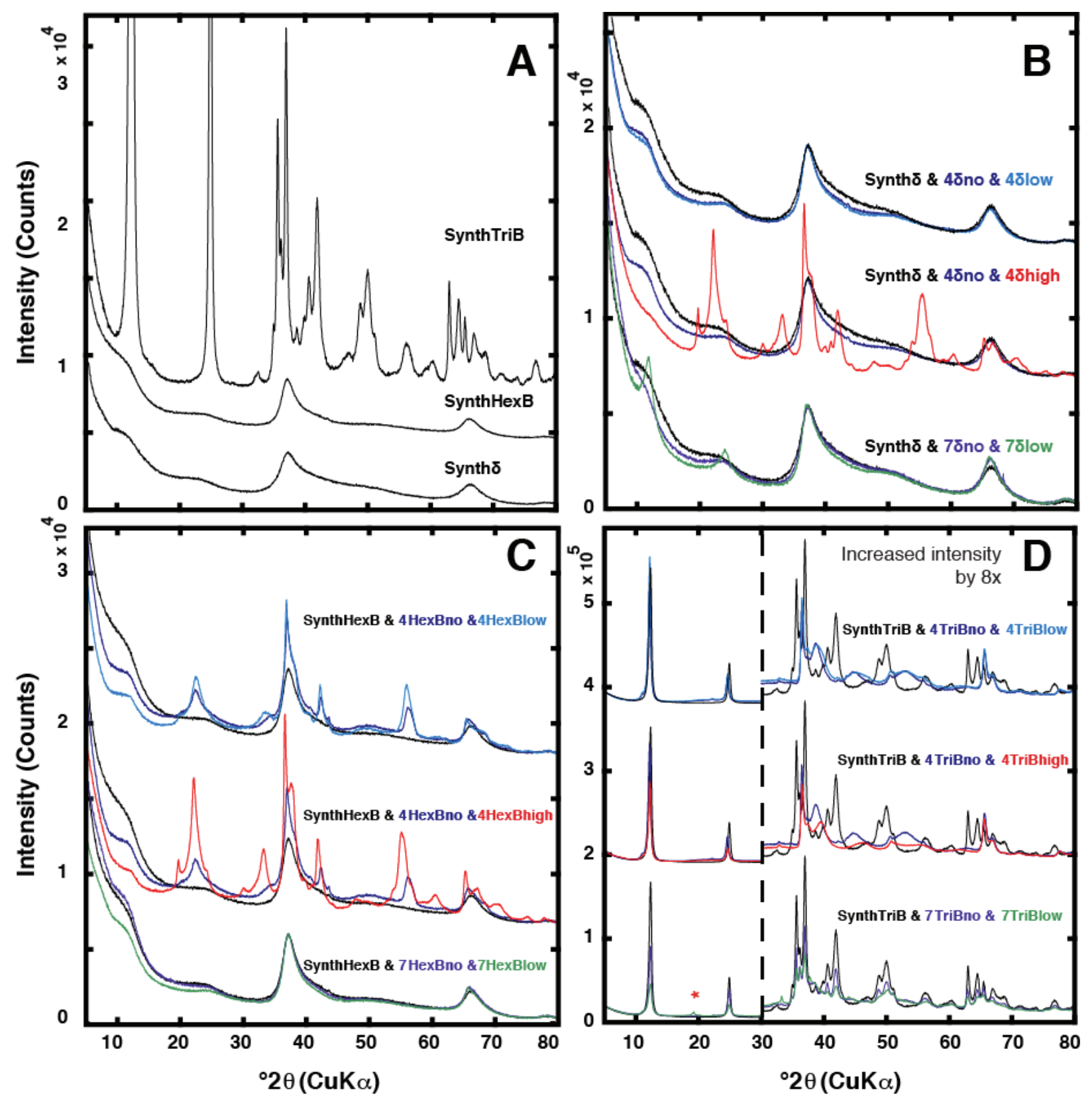

Figure 1. XRD patterns of unreacted manganese oxides (A) and of $\delta$-MnO2 (B), HexB (C), and TriB (D) after aging for 25 days in the absence or presence of dissolved Mn(II); see Table 2 for specific conditions. In (B-D), patterns of the unreacted samples (black) and samples reacted without $\mathrm{Mn}$ (II) (see legend) are overplotted by the pattern of the corresponding sample reacted with Mn(II) (see legend). The red asterisk in (D) denotes a peak corresponding to feitknechtite. The vertical dashed line in (D) demarcates an intensity scale change from $1 \times$ to $8 \times$ intensity. 

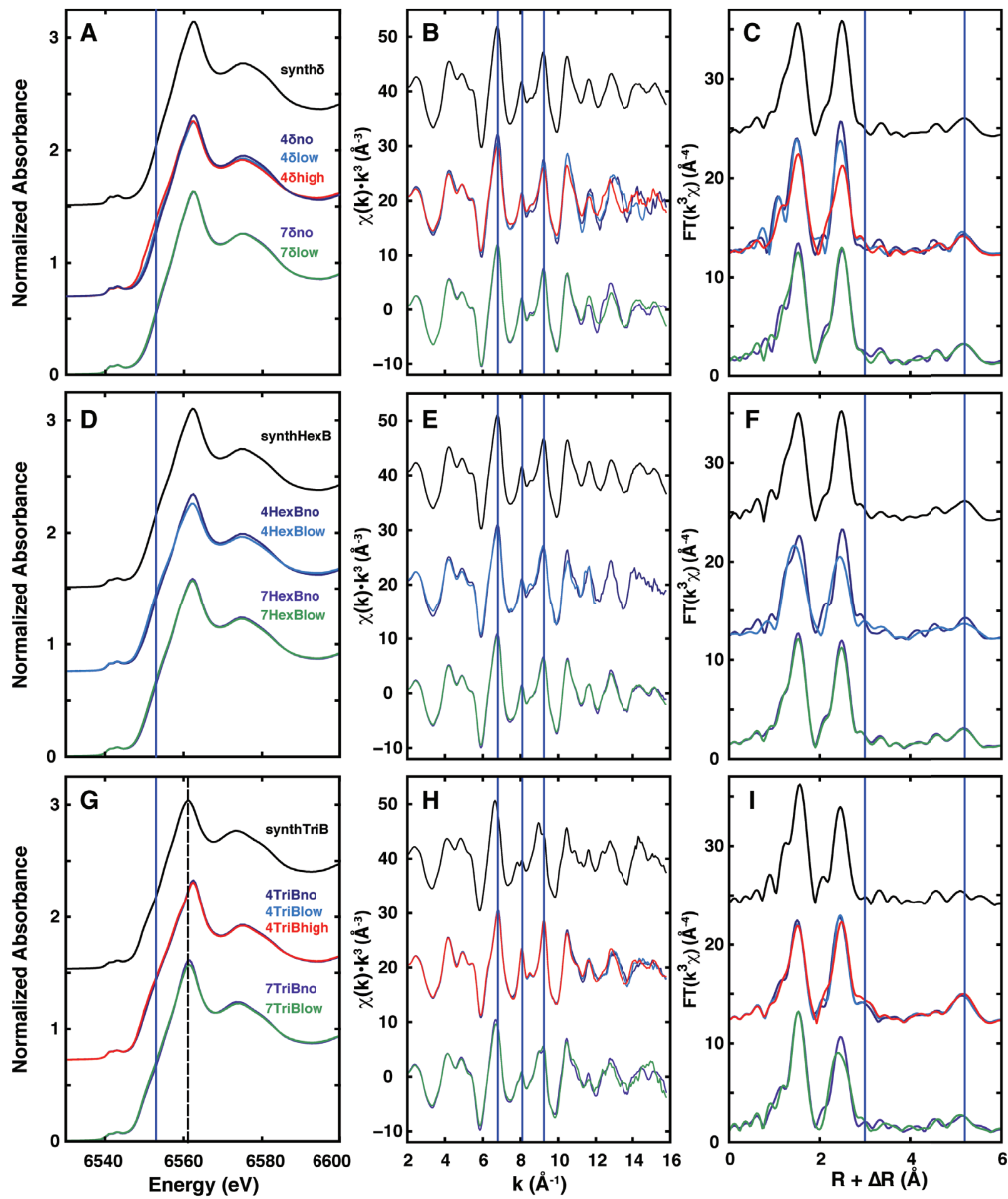

Figure 2. Mn K-edge XAFS spectra of unreacted and reacted $\delta-\mathrm{MnO}_{2}(\mathrm{~A}-\mathrm{C}), \mathrm{HexB}(\mathrm{D}-\mathrm{F})$, and TriB (G-I); see Table 2 for specific conditions. XANES spectra (A,D,G), EXAFS spectra $(\mathrm{B}, \mathrm{E}, \mathrm{H})$, or Fourier transform $(\mathrm{C}, \mathrm{F}, \mathrm{I})$ data of the aged samples are overplotted with one another for each $\mathrm{pH}$ set. Vertical blue lines denote diagnostic features at $6553 \mathrm{eV}$ in the XANES spectra, 6.8, 8.1, and 9.2 $\AA^{-1}$ in the EXAFS spectrum, and 3.0 and $5.2 \AA$ in the EXAFS Fourier transform; the vertical black dashed line indicates the white line energy of unreacted triclinic birnessite. XAFS spectra of samples reacted with $7.5 \mathrm{mM} \mathrm{Mn(II)} \mathrm{at} \mathrm{pH} 7$ appear in Figure 4. 

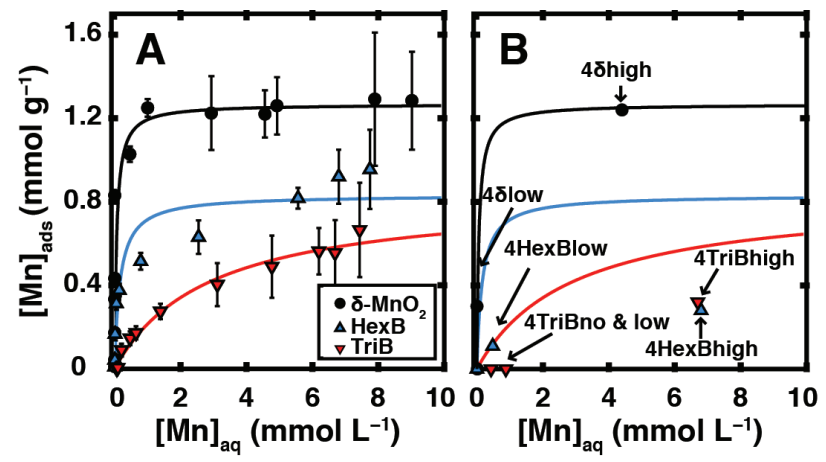

Figure 3. (A) $\mathrm{Mn}(\mathrm{II})$ adsorption isotherms at $\mathrm{pH} 4$ after 2 days of reaction. Lines represent Langmuir isotherm fits to the data (see Table EA1). (B) Mn(II) uptake (points) onto phyllomanganates after 25 days of reaction at $\mathrm{pH} 4$ compared to Langmuir isotherm curves determined from the 2 day $\mathrm{Mn}(\mathrm{II})$ adsorption isotherm measurements.
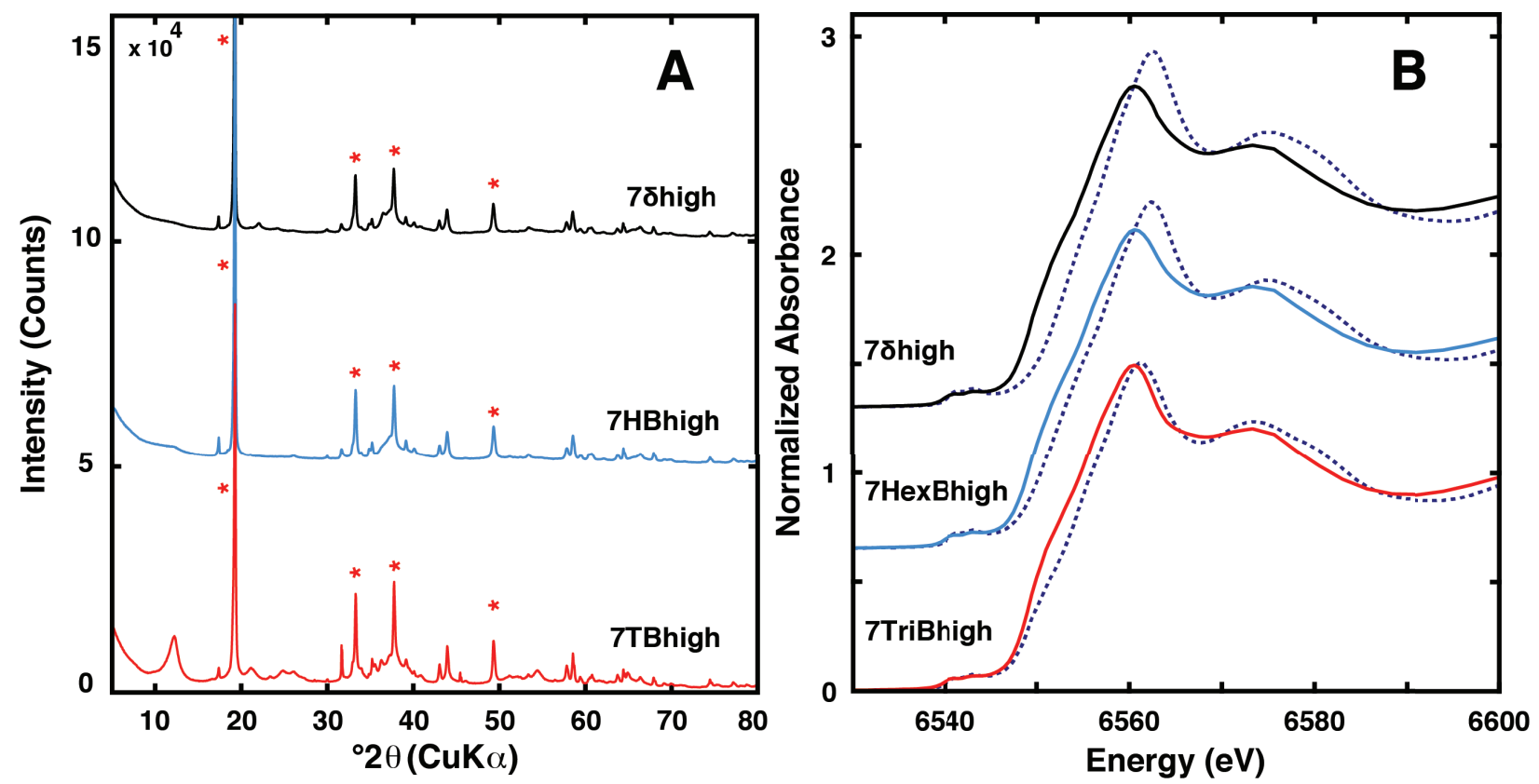

Figure 4. XRD patterns (A) and XANES spectra (B) of phyllomanganates reacted for 25 days with $7.5 \mathrm{mM} \mathrm{Mn(II).} \mathrm{Peaks} \mathrm{corresponding} \mathrm{to} \mathrm{feitknechtite} \mathrm{in} \mathrm{XRD} \mathrm{are} \mathrm{denoted} \mathrm{by} \mathrm{red} \mathrm{asterisks.}$ Dotted lines represent XANES spectra of the corresponding unreacted phyllomanganate. 